Board of Governors of the Federal Reserve System

International Finance Discussion Papers

IFDP 1058

November 2012

\title{
Crisis and Calm: Demand for U.S. Currency at Home and Abroad from the Fall of the Berlin Wall to 2011
}

\author{
Ruth Judson
}

NOTE: International Finance Discussion Papers are preliminary materials circulated to stimulate discussion and critical comment. References to International Finance Discussion Papers (other than an acknowledgment that the writer has had access to unpublished material) should be cleared with the author or authors. Recent IFDPs are available on the Web at www.federalreserve.gov/pubs/ifdp/. This paper can be downloaded without charge from Social Science Research Network electronic library at www.ssrn.com. 


\title{
Crisis and Calm: Demand for U.S. Currency at Home and Abroad from the Fall of the Berlin Wall to 2011
}

\author{
Ruth Judson $^{*}$
}

\begin{abstract}
:
U.S. currency has long been a desirable store of value and medium of exchange in times and places where local currency or bank deposits are inferior in one or more respects. Indeed, as noted in earlier work, a substantial share of U.S. currency circulates outside the United States. Although precise measurements of stocks and flows of U.S. currency outside the United States are not available, a variety of data sources and methods have been developed to provide estimates.

This paper reviews the raw data available for measuring international banknote flows and presents updates on indirect methods of estimating the stock of currency held abroad: the seasonal method and the biometric method. These methods require some adjustments, but they continue to indicate that a large share of U.S. currency is held abroad, especially in the $\$ 100$ denomination. In addition to these existing indirect methods, I develop a framework and basic variants of a new method to estimate the share of U.S. currency held abroad.
\end{abstract}

Although the methods and estimates are disparate, they provide support for several hypotheses regarding cross-border dollar stocks and flows. First, once a country or region begins using dollars, subsequent crises result in additional inflows: the dominant sources of international demand over the past decade and a half are the countries and regions that were known to be heavy dollar users in the early to mid-1990s. Second, economic stabilization and modernization appear to result in reversal of these inflows. Specifically, demand for U.S. currency was extremely strong through the 1990s, a period of turmoil for the former Soviet Union and for Argentina, two of the largest overseas users of U.S. currency. Demand eased in the early 2000s as conditions gradually stabilized and as financial institutions developed. However, this trend reversed sharply with the onset of the financial crisis in late 2008 and has continued since then.

Keywords: Currency, banknotes, dollarization, crisis

JEL classification: C82, E4, E49

The author is a staff economist in the Division of International Finance, Board of Governors of the Federal Reserve System, Washington, DC 20551 U.S. A. The views in this paper are solely the responsibility of the author and should not be interpreted as reflecting the views of the Board of Governors of the Federal Reserve System or of any other person associated with the Federal Reserve System. 


\section{Crisis and Calm: Demand for U.S. Currency at Home and Abroad from the Fall of the Berlin Wall to $2011^{1}$}

Unlike the banknotes of most other countries, the U.S. dollar is used far beyond its borders as a medium of exchange and store of value. This international aspect of dollar usage has important implications for a wide range of Federal Reserve operational considerations, including its currency production, processing, and planning, the interpretation of currency figures as part of monetary analysis, daily open market operations, management of the Federal Reserve's portfolio, and analysis and forecasting of the Federal Reserve's income. ${ }^{2}$ In addition, currency exports, like other exports, figure in the U.S. balance of payments and international investment position. Unfortunately, however, direct measurements of the stocks and flows of U.S. currency outside U.S. borders are not available, and a variety of indirect measurements and proxies must instead be used. From these sources, though, a fairly consistent picture emerges.

Despite the disparate methods and data sources, the data consistently indicate several trends. First, international demand for U.S. currency increased steadily over the 1990s and into the early 2000s, a period that coincided with the fall of the Berlin Wall, the collapse of the Soviet Union, and periodic economic and political crises in several Latin American countries. Second, international demand for dollars began to stabilize or decline around the time of the introduction

\footnotetext{
${ }^{1}$ Valentin Bolotnyy did a superb job of updating and organizing many of the estimates presented here, and his work was instrumental in the corrections to the biometric method reviewed in section 3. In addition, this work would have been impossible without the generous assistance of, and thought-provoking discussions with, Dick Porter (FRB-Chicago); Joann Freddo, Eileen Goodman, Jeff Pruiksma, Elliot Shuke, and Charles Sims (FRB-New York); Carol Bertaut, Neil Ericsson, Jaime Marquez, John Roberts, Charlie Thomas, Shaun Ferrari, Michael Lambert, and Lorelei Pagano (Board of Governors); and Ed Feige. All errors and omissions are mine.

${ }^{2}$ Until late 2008, Federal Reserve notes, the dominant form of currency, were the primary liability on the Federal Reserve's balance sheet. As a result, currency demand was thus a primary consideration in the conduct of daily open market operations as well as in longer-range planning related to the Federal Reserve's System Open Market Account portfolio. After late 2008, deposits of depository institutions (of which reserve balances are the vast majority) increased significantly and now exceed currency as a liability on the Federal Reserve's balance sheet. Appendix Figure 3 illustrates the major components of the Federal Reserve's balance sheet since 2003.
} 
of the cash euro in 2002. ${ }^{3}$ This decline coincided with economic and political stabilization and financial modernization in many economies in and around the euro zone and the former Soviet Union and continued until late 2008, when the global financial crisis appeared to spark renewed demand for U.S. banknotes that has shown no sign of abating.

In this paper, I present estimates of the stocks and flows of U.S. currency abroad from the early 1990s through the end of 2011. Section 1 reviews the available data sources, with a focus on their strengths and weaknesses for use in answering questions about the shares of banknotes held in the United States and abroad. Section 2 presents an overview of currency demand over the past several decades and some stylized facts about the composition of U.S. currency levels and changes over time. Section 3 builds on these stylized facts and presents simple and direct estimates of stocks and flows of U.S. currency abroad. Section 4 presents updates of two indirect estimates of stocks and flows of U.S. currency held abroad; these estimates are based on the data sources from Section 1 as well as additional information. Section 5 presents estimates of a very simple currency demand equation for the United States, from which estimates of the impact of international demand on currency growth can be derived. Section 6 summarizes these findings and concludes with some general observations and directions for further work.

\footnotetext{
${ }^{3}$ The euro currency was introduced as a unit of account in 1999; the physical currency was introduced in 2002.
} 


\section{Data: An Overview}

\section{I.A. Total Currency in Circulation}

\section{I.A.1. Public Data}

In general, the aggregate quantity of genuine currency in circulation is relatively easy to measure: it is physical, and it is produced, transported, and issued under very secure conditions. ${ }^{4}$ Official currency statistics for the United States are reported by the Treasury and Federal Reserve, which collaborate to produce data on currency in circulation, generally defined as Federal Reserve notes, Treasury currency, and coin held outside of the vaults of the Federal Reserve and the Treasury. ${ }^{5}$ Figures on total currency in circulation are reported weekly on the Federal Reserve's H.4.1 and H.6 Statistical Releases; the quarterly Treasury Bulletin provides additional detail on denominations of banknotes and coin in circulation.

\section{I.A.2. Internal Data}

The Federal Reserve's internal accounting and production processes require close monitoring of currency production, processing, and movements; as a result, more frequent and detailed data are available internally for Federal Reserve notes, which constitute the vast majority of currency in circulation $(\$ 1.03$ trillion of the $\$ 1.08$ trillion total as of the end of 2011). ${ }^{6}$ In particular, accounting data provide daily updates by denomination on the quantity of Federal Reserve notes outstanding (that is, carried on the books of each Federal Reserve Bank), and in the custody of each Federal Reserve Bank. In addition, processing data provide monthly

\footnotetext{
${ }^{4}$ The quantity of counterfeit currency in circulation at any point is not known, but estimates suggest that circulating counterfeits are extremely small relative to genuine currency, on the order of one to three in 10, 000 (Judson and Porter (2010)).

${ }^{5}$ Appendix table 1 provides a list of sources of currency data along with a description of the different definitions of currency.

${ }^{6}$ H.4.1 Statistical Release, tables 1 and 8. http://www.federalreserve.gov/releases/h41/20111229/.
} 
totals of Federal Reserve note movements between each Federal Reserve office and circulation

by denomination. ${ }^{7}$ As shown in section 3 , these data and simplifying assumptions about domestic and international movements of banknotes can be exploited to obtain estimates of stocks and flows of U.S. currency abroad.

\section{I.B. Data on Cross-Border Flows of U.S. Currency}

Movements of currency across U.S. borders cannot be precisely measured for several reasons. First, there is no legal requirement or mechanism to monitor movements of $\$ 10,000$ or less, and many individuals cross U.S. borders each year. ${ }^{8}$ The net movements of currency across U.S. borders through such nonbanking channels are potentially significant. Indeed, as noted in U.S. Treasury (2006), customs reporting for Mexico indicates substantial cash flows from the United States to Mexico in the hands of tourists and migrants; such flows, since they typically occur in amounts of less than $\$ 10,000$ and through nonbanking channels, are not captured in U.S. data. Second, even when there is a legal requirement to report currency flows, mechanisms are not always in place to capture the data and reporters might not comply with requirements.

Despite these challenges, informative measurements do exist.

\section{I.B.1. Federal Reserve Commercial Bank Shipment Data}

The Federal Reserve provides currency on demand to all account holders, including those who provide banknotes to international customers. Many of these institutions, including most of the largest wholesale banknote dealers, report monthly, on a voluntary and confidential basis, the value and ultimate source or destination country of their receipts and payments of U.S. currency.

\footnotetext{
${ }^{7}$ The locations and boundaries of the twelve Federal Reserve districts were set when the Federal Reserve was established in 1913. Within each district, cash processing occurs at one or more cash offices. The number and location of these offices varies over time. Processing data are reported separately for each office.

${ }^{8}$ In 2009, 151 million passengers arrived and departed on international flights at U.S. airports and about 200 million border crossings occurred by land (U.S. Census 2012).
} 
While not all banks that deal in the international shipment of banknotes provide these reports, the banknote shipping business is highly concentrated and this dataset currently captures the vast majority of banknote shipments that cross U.S. borders through commercial banking channels.

This dataset begins in the late 1980s and covers virtually every country in the world. The quality of the data varies across time as the set of reporting dealers has evolved; for all practical purposes, the dataset begins in the early 1990s. For example, consider a shipment bound for Russia via Germany. The immediate source or destination of the shipment can be identified by the location of the counterparty. Thus, for a nonreporting dealer, the dataset would only indicate a shipment to Germany, but a reporting dealer would provide the ultimate destination, Russia. Conversely, consider a shipment from Cambodia back to the United States via Hong Kong. Data from a nonreporting dealer would indicate an inflow of dollars to the United States from Hong Kong, but data from reporting dealer would indicate the ultimate source of shipment as Cambodia. The level of detail in the reporting has generally improved over time as more dealers have begun to report, but the trend can reverse if, for example, a reporting banknote dealer leaves the banknote business and other nonreporting dealers begin providing banknote shipment services to the departing reporter's customers.

Two additional shortcomings of this dataset are that it covers only banknote flows to and from the United States, and that it only covers flows through the banking system. First, the dataset does not cover U.S. banknote flows among other countries, which can be substantial, especially in areas where large volumes of cross-border trade are conducted in cash. ${ }^{9}$ The absence of such information complicates any estimation of regional or country-level holdings outside the United States, but does not affect aggregate measurements of commercial bank

\footnotetext{
${ }^{9}$ Refer to U.S. Treasury (2006) for examples of such flows.
} 
currency shipment flows into and out of the United States. However, banknote flows through nonbank channels can also be significant, and observations gathered in the course of the joint U.S. Treasury - Federal Reserve International Currency Awareness Program indicate that several countries receive dollar inflows through nonbank channels such as tourists or migrant workers but return the currency to the United States through banking channels. ${ }^{10}$ As a result of these shortcomings and complications, the country-level data must be interpreted with care and with an understanding of the institutional arrangements in place through time.

\section{I.B.2. U.S. Customs Data}

In principle, the most obvious direct source of information on U.S. currency flows across U.S. borders should be the Currency and Monetary Instrument Reports (CMIRs), which are compiled by the U.S. Customs Service. Individuals and firms making almost any shipment of more than $\$ 10,000$ in cash across a U.S. border are required to file CMIRs, so these reports should be quite comprehensive and informative. However, as noted in Treasury (2006), CMIRs are neither accurate nor thorough measures of large cash shipments outside the banking sector due to three shortcomings: a generally one-sided system for collecting data, the omission of some potentially large volumes of currency flows, and the inability to accurately reflect flows to international custodial holding sites for U.S. currency. First, all individuals entering or leaving the United States are required to complete a CMIR if they are carrying more than $\$ 10,000$ in currency or monetary instruments. In practice, though, customs formalities, including a specific question about currency and monetary instruments, are required for individuals entering the United States, but not for individuals exiting the United States. ${ }^{11}$ As a result, it seems plausible

\footnotetext{
${ }^{10}$ This phenomenon is addressed in more detail in the discussion of the flow data.

${ }^{11}$ Passengers on flights departing the United States are sometimes questioned or informed about this reporting requirement, but coverage is far from complete.
} 
that underreporting is more likely for outbound travels. Second, even if all travelers were to report accurately, the CMIRs require no reporting for sums below $\$ 10,000$; in aggregate, these sums could be considerable. As noted above, 151 million passengers arrived and departed on international flights at U.S. airports and about 200 million border crossings occurred by land in 2009 (U.S. Census 2012). Third, the CMIRs do not account properly for shipments to international custodial holding sites for U.S. currency. These sites, known as Extended Custodial Inventories, or ECIs, are secure locations outside the United States at which U.S. currency is held in custody for the Federal Reserve Bank of New York. Shipments to these sites are recorded in U.S. Customs data when they physically exit the United States, even though they remain in the custody of the Federal Reserve Bank of New York. Thus, for example, a shipment to an ECI in Switzerland will be recorded as a shipment to Switzerland on the day it occurs even though the currency is not in circulation. ${ }^{12}$

In addition, CMIR reporting requires only information about the immediate source or destination of currency flows, not the ultimate source or destination like the commercial bank shipment data. For example, if an institution ships currency to Russia via Germany, the commercial bank shipment data from a reporting institution would record the destination as Russia while the CMIR data would report the destination as Germany. We therefore consider the shipments data described above to be superior to the CMIR data, and hence we do not use the CMIR data in this study. ${ }^{13}$

\footnotetext{
${ }^{12}$ Refer to U.S. Treasury (2006), Chapter 5, for more details about ECIs.

${ }^{13}$ For researchers who do not have access to the shipment data, or for certain countries and time periods, the CMIR data can provide useful insights. Refer, for example, to Feige $(1996,2012)$ for analysis of the U.S. economy and to Kamin and Ericsson (2003) for analysis of dollarization in Argentina. For the latter analysis, CMIR data were both available over a longer time period and more reliable than usual because of the patterns of dollar flows to Argentina.
} 


\section{Stylized Facts about U.S. Currency in Circulation}

\section{II.A. Overall Currency Growth Has Been Strong}

The death of cash has often been predicted, and it would seem that demand for currency would thus grow somewhat more slowly than income. Despite a general increase in the variety of payment media as well as increasing noncash means of payment, though, U.S. currency in circulation has grown at an average rate of about 6 to 7 percent annually over the past few decades, one to two percentage points more rapidly than U.S. nominal GDP. ${ }^{14} 15$

\section{II.B. Overall U.S. Currency Movements are Dominated by $\$ 100 s$}

In value terms, the driving force over this period has generally been growth in the $\$ 100$ denomination, as can be seen in Figures $1 \mathrm{~A}$ and $1 \mathrm{~B} .{ }^{16}$ Figure $1 \mathrm{~A}$ presents annual end-year data on U.S. currency in circulation by denomination from 1989 to 2011 . At the end of 2011, U.S. currency in circulation totaled about $\$ 1$ trillion, of which nearly $\$ 800$ billion, or just over three quarters, was in the $\$ 100$ denomination. ${ }^{17}$ Figure 1B presents annual growth rates for the same items, on a fourth-quarter-to-fourth-quarter basis. The overall growth of currency, the solid black line, moves closely with, though generally more slowly than, the growth of $\$ 100$ notes, the dashed purple line. The correlation of overall currency growth with $\$ 100$ s over this period is over 0.9 ; correlations with the other denominations are generally decreasing in the denomination. The correlation for $\$ 1 \mathrm{~s}$ is about 0.2 .

\footnotetext{
${ }^{14}$ On a Q4-to-Q4 basis, over 1980-2011, currency growth averaged 71/4 percent and nominal GDP growth averaged 53/4 percent. Over 1990-2011, currency growth averaged 7 percent and nominal GDP growth averaged 43/4 percent. Over 1999 to 2011, currency growth averaged 6 percent and nominal GDP growth averaged 41/4 percent.

${ }^{15}$ Refer to BIS (2012).

${ }^{16}$ In piece terms, however, U.S. currency is dominated by smaller denominations. As of late $2011, \$ 1$ s were $32 \%$ of notes in circulation, $\$ 2 \mathrm{~s}$ to $\$ 10 \mathrm{~s}$ were $16 \%$, and $\$ 100$ s were $25 \%$. Appendix Figures $1 \mathrm{~A}$ and $1 \mathrm{~B}$ provide a breakdown of U.S. and Canadian currency by denomination in value and piece terms.

${ }^{17}$ These figures are from the Treasury Bulletin: http://www.fms.treas.gov/bulletin/b2011_1.pdf.
} 


\section{II.C. Crises Are Reflected in Aggregate U.S. Currency Data}

Figure 1B begins to reveal some general patterns in overall currency demand. In particular, currency growth was quite strong in the early 1990s, which coincided with the fall of the Berlin Wall and the collapse of the Soviet Union. After a brief lull in the mid-1990s, currency growth picked up again in the late 1990s, driven by crisis in Argentina in 1997 and then concern about Y2K in 1998 and 1999. Following a dip in currency demand in 2000, which largely reflected the return early in 2000 of precautionary stocks accumulated late in 1999, demand was boosted in the early 2000s by the events of September 11, which, judging by outsized commercial bank shipments, led to strong overseas demand for currency in the short run and, in the longer run, the apparent accumulation of precautionary stocks at home and abroad. Demand then slowed over the mid- to late-2000s until the sharp reversal seen in late $2008{ }^{18}$

\section{II.D. Canadian Patterns of Currency Demand Are Likely Similar to U.S. Domestic Currency Demand}

One might look to Canada for evidence of what U.S. currency demand would look like without a foreign component. Canada has similar income levels, payments technologies, holiday patterns, and GDP growth rates to those in the United States, but little Canadian currency is believed to circulate externally. Figures 2A and 2B display Canadian currency in circulation by denomination in levels and growth rates from 1989 to 2011. As can be seen in Figure 2A, \$100s are also prevalent in Canada, though less dramatically than in the U.S., accounting for just over half of Canadian currency in circulation at the end of $2011 .{ }^{19}$ Overall currency growth rates for Canada are, not surprisingly, driven less strongly by $\$ 100$ s and more strongly by $\$ 20$ s and $\$ 50$ s

\footnotetext{
${ }^{18}$ Hellerstein and Ryan (2011) find systematic relationships between currency shipments and inflation and other factors.

${ }^{19}$ Both the United States and Canada have notes of denominations above $\$ 100$ in circulation, but in both cases, these notes have not been issued to circulation for some time.
} 
(not shown), the primary transaction denominations in Canada. Over the full half-century, the simple correlation between overall currency growth and growth by denomination is $84 \%$ for $\$ 100$ s, $86 \%$ for $\$ 20$ s, and $75 \%$ for $\$ 50$ s. More recently, however, the role of $\$ 100$ s has apparently declined, possibly as electronic payments have become more common. Correlations over this period are, respectively, $63 \%, 87 \%$, and $70 \%$.

\section{II.E. U.S. and Canadian Currency Growth Relative to Income Diverged Beginning in the 1980s}

As noted earlier, U.S. currency growth has been strong even relative to nominal GDP. Figures 3 and 4 display the ratios of total currency to nominal GDP for the United States and Canada over the past half-century. Ordinary theories of money demand would predict that the ratio of income to currency, or velocity (the inverse of the ratio shown here) should vary positively with the opportunity cost of holding money. That is, in terms of these charts, higher opportunity cost would be associated with lower demand for currency relative to income. As cashless payments become more common and, presumably, more cost-effective, one might expect that, abstracting from movements in market interest rates, demand for currency relative to income should decline. Indeed, that pattern prevailed in the United States until about 1985, and in Canada generally for the period. The upturn in the U.S. ratio of currency to nominal GDP beginning in 1989 is thus anomalous and is consistent with substantial and growing external use of U.S. currency.

In the next section, I present a very simple estimate of overseas demand for U.S. currency based on these patterns and the assumption that patterns of domestic demand for currency are the same in the United States and Canada. I then juxtapose these estimates with direct measurements of cross-border currency flows. 


\section{Simple Estimates of Stocks and Flows of U.S. Currency Held Abroad III.A. Two Estimates Based on Money Demand and Comparisons with Canada}

\section{III.A.1. A Very Simple Estimate}

Taken together, the difference between the patterns seen for the United States and for Canada in Figures 3 and 4 suggest a simple estimate of the share of U.S. currency abroad. As noted above, and as displayed in Figure 5, U.S. and Canadian nominal GDP growth rates have been similar over this period. The observed U.S. ratio of currency to nominal GDP is the sum of domestic and foreign demand. If we assume that the Canadian ratio of currency to nominal GDP is the same as its U.S. counterpart for domestic demand, then the foreign share of U.S. demand can be estimated as follows. Define

(1) $C U R R G D P_{\text {Canada }}=\frac{C U R R_{\text {Canada }}}{G D P_{\text {Canada }}}$

(2) $C U R R G D P_{U S A}=\frac{C U R R_{U S A}}{G D P_{U S A}}=\frac{C_{U R R} R_{U S A D o m}}{G D P_{U S A}}+\frac{{ }^{C U R R_{U S A F o r}}}{G D P_{U S A}}$

$$
=C U R R G D P_{U S A_{-} D o m}+C U R R G D P_{U S A_{-} F o r}
$$

Replacing CURRGDP USA_Dom with CURRGDP $_{\text {Canada }}$ in the equation above, it is then possible to solve for CURRUSA_For / CURRUSA_Tot as

(3) ForShare $_{\text {Verysimple }} \equiv \frac{\operatorname{CurrUSA}_{\text {For }}}{\operatorname{CurrUSA}_{\text {Total }}}=1-\left(\frac{\operatorname{CurrGDP}_{\text {Canada }}}{\operatorname{CurrGDP}_{U S A}}\right)$

\section{III.A.2. A Simple Estimate}

The approach above carries with it the assumption that Canadian and U.S. domestic demand for currency are the same at the same point in time. However, the level of Canadian per capita income, while similar to that of the United States, has generally been a bit lower. Thus, an 
alternative assumption would be that Canadian and U.S. domestic demands for currency relative to income are the same at the same levels of per capita income. In order to construct an estimate of the share of U.S. currency abroad using this assumption, we proceed as follows. First we regress the ratio of Canadian currency to GDP on the log and level of Canadian per capita GDP, denoted GDPC:

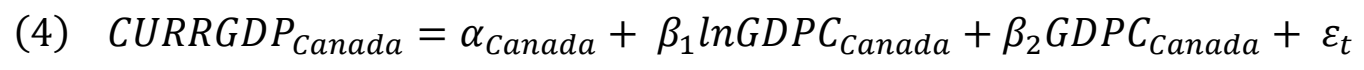

To be sure, this specification is a very simple reduced form based on the chart shown; it effectively assumes a log-linear structure for demand for currency as a function of income and assumes no other factors. We then construct the estimated domestic share of U.S currency for a given level of GDPC as

(5) $\quad$ CURRGD $P_{\text {USADom }}=\alpha_{\text {Canada }}+\beta \ln \left(G D P C_{U S A} * X_{\text {CanUS }}\right)$

where $\mathrm{X}_{\text {CanUS }}$ is the U.S.-Canadian dollar exchange rate. The simple estimate is then constructed as before, replacing CURRGDP USADom $_{\text {with } C U R R \widehat{G D P}_{U S A D o m} \text { rather than CurrGPD }}$ Can in

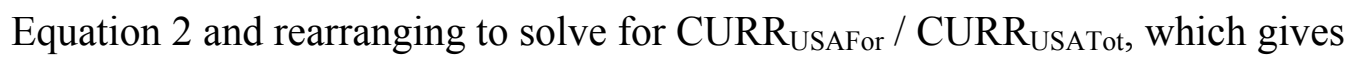

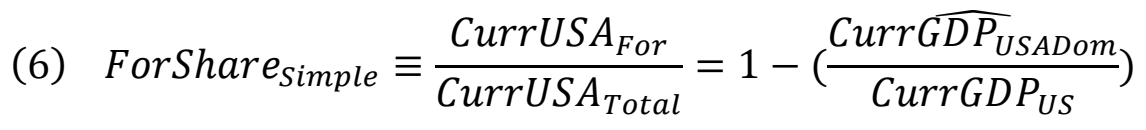

These two estimates of U.S. currency abroad are displayed in Figures 6A and 6B. The GDP-based estimates, the solid lines, suggest that about half of all U.S. currency, and about 65 percent of $\$ 100$ s, were held abroad as of the end of 2011, for a total value of about $\$ 500$ billion. Over the past two decades, these estimates point to a sharp runup in external demand for U.S. currency beginning in the late 1980s, a brief pop in 1999, a decline beginning in 2003, and a resurgence in 2008, all patterns consistent with the overall growth of U.S. currency. 


\section{III.B. Measurements of Cross-Border Flows of U.S. Currency}

We now turn to the information provided by direct measurements of currency flows.

Figures 7 through 11 display annual data on the primary measurements of cross-border currency flows in dollars, the international commercial bank shipment data described in Section I.B.1. Beginning with Figure 7, the solid black line indicates net commercial bank shipments and the dashed blue line indicates the total change in currency in circulation each year. ${ }^{20}$ Focusing only on the solid black and blue dashed lines, several features of the data stand out. First, reflecting the strong influence that international demand has on overall U.S. currency demand, the two series generally move in parallel, though the gap widens in the early 2000s and narrows in the most recent years. Second, the spike seen in total currency in circulation, the blue dashed line, is absent in the shipment flows. This feature of the data reflects the fact that a large share of the runup in holdings of currency immediately prior to the century date change (that is, in the final weeks of 1999) was held in commercial bank vaults and was then returned to the Federal Reserve early in 2000. Thus, while the currency was technically "in circulation" in the sense that it was held outside the Federal Reserve, the bulk of it never went to bank customers. ${ }^{21}$

While U.S. currency is used in, and is shipped to and from, many countries, a few areas stand out because of their size and their appetite for dollars in times of crisis. In Figure 8, the dashed red line indicates net commercial bank shipments to the two leading markets in this category, the former Soviet Union and Argentina. For all but the first and last few years of the period shown, or from about 1995 to 2008, these shipments more than fully accounted for all net

\footnotetext{
${ }^{20}$ Net commercial bank shipments are defined as shipments out of the United States to other countries (exports) less shipments from other countries into the United States (imports).

${ }^{21}$ For many internal calculations, we typically smooth through this spike because of its extremely transitory and peculiar nature. The currency component of the money stock excludes currency held in the vaults of depository institutions. We would ordinarily prefer to use this currency component measurement, but data are not available by denomination on that basis.
} 
commercial bank shipments. This phenomenon might also have been the case in the early part of the sample, but reporting in that period was not as detailed. As a result, shipments recorded with a destination of Europe might well have been sent to the former Soviet Union. In the early 2000s, net shipments to these markets declined as the financial conditions stabilized and as the need to use cash for saving and transactions has faded. In the past two years, though, global conditions as well as crisis and political uncertainty in these regions appears to have coincided with an upswing in demand for dollars. ${ }^{22}$

Figure 9 displays a proxy for commercial bank shipments based on currency processing data, the solid gray line. Commercial bank shipments are reported on a confidential basis, and monthly data are not always available on a consistent schedule. In order to have data for operational and publication purposes, Federal Reserve Board staff developed this proxy, which is the sum of net payments of $\$ 100$ notes from three Federal Reserve offices known to handle substantial volumes of deposits and withdrawals sent from or to international destinations: New York, Los Angeles, and Miami. ${ }^{23}$ This proxy is based on two assumptions, which differ from the true net shipments series in two offsetting ways. The first assumption, which likely results in an overestimate, is that all payments and receipts at these offices are to or from international counterparties and that all payments and receipts at other offices are to or from domestic entities; in fact, every Federal Reserve office serves domestic and international customers. The second assumption, which would generally result in an underestimate, is that only $\$ 100$ s are sent to or received from international destinations. This proxy moved very closely with the total shipments

\footnotetext{
${ }^{22}$ Work on disentangling the relative importance of internal and external economic and political crisis for currency demand in these countries is currently underway.

${ }^{23}$ The Federal Reserve System has 12 regional Banks, whose locations are fixed. Many Federal Reserve Banks also have one or more branches, whose number and location can change over time as operational needs dictate. The Miami office is a branch of the Federal Reserve Bank of Atlanta and the Los Angeles office is a branch of the Federal Reserve Bank of San Francisco.
} 
data in the 1990s, but was considerably higher than shipments over most of the 2000s, perhaps suggesting that domestic demand for $\$ 100$ s was stronger in that period.

The two dashed series in Figure 9 indicate two experimental series. As noted above, one shortcoming of the shipment dataset is that it captures only cross-border flows carried through commercial banking, or "wholesale" channels. However, as reported in U.S. Treasury (2006), many countries receive large dollar flows through nonbank, or "retail" channels and return dollars to the United States through banking channels. In the commercial bank shipment data, this phenomenon emerges in the form of persistent negative net shipment figures. That is, the shipment figures indicate large flows of dollars out of the foreign country into the United States and much smaller flows in the opposite direction.

For some such countries, the net commercial bank shipments figures are likely accurate and reflect dollar banknote inflows from third countries. For example, if tourists from Country A routinely carry dollars to Country B and the residents of Country B have little other use for dollars, the dollars might be shipped from Country B to the United States. All other factors equal, this pattern would result in negative net shipments figures, and shipments figures summed across Country A and Country B would give an accurate indicate of flows into and out of the United States. For some countries, however, it is likely that dollars arrived in the country from the United States through nonbank channels. In such cases, the commercial banknote flows would not give an accurate indication of net flows to and from the United States.

The first experimental series imposes a very rough adjustment for this phenomenon as follows. First, a group of countries known to have significant tourism or significant populations of immigrants or migrant workers in the United States is identified. Second, a group of countries whose total net shipments is substantial and negative is identified. Third, for each year and for 
each country in both groups, the assumption is imposed that total net currency shipments to these countries, including the observed net commercial bank "wholesale" flows and nonbank "retail" flows, were zero.

As with the shipments proxy, this approach embodies two assumptions. First, this approach implicitly assigns a value of zero for net currency flows to these countries. This assumption could be erroneous in either direction: actual net flows could be positive or negative. Second, this approach assumes that other countries' flows in aggregate are accurately measured by net commercial bank shipments. The blue dashed line shown here displays an adjustment that imposes this assumption for about a dozen countries. While this approach is admittedly crude, it is suggestive of the magnitude of flows that could be occurring through nonbank, or "retail" channels. Ideally, we could refine this measure by constructing series of "retail" (nonbank channel) banknote flows from the United States to other countries. While this type of data is not available universally, it is collected by some countries, including Mexico. ${ }^{24}$ This measure, the dashed black line, also tracks the shipments proxy for most of the sample, though it becomes implausibly large in the last few years of the sample. To the extent that this adjustment it useful, it is probably more applicable for cumulative, or stock estimates, than it is for flow estimates, because the nonbank flows likely occur at different times than the measured banking-channel flows back to the United States. For example, currency might be brought from the United States

\footnotetext{
${ }^{24}$ Mexico is the largest single contributor to this adjustment, and it was the case of Mexico that inspired this approach. In the 1990s, Mexico collected customs data on cash imports from all travelers with no lower bound on the reporting threshold. This reporting is, of course, subject to the same problems of underreporting as other customs data, but the magnitudes were substantial and of a magnitude similar to reported commercial bank inflows. More recent customs reporting requires only declaration of amounts above $\$ 10,000$. Regardless, Mexican statistics on tourism flows indicate substantial volumes of people and revenue, though the form of the revenue (cash, credit card, or other) is not specified. Refer to Banco de Mexico (2012).
} 
to another country through nonbanking channels over time and then return quickly in the event of a regulatory or other political or economic change.

Finally, the dashed gray line is an adjusted shipment proxy series. Along the lines of the adjusted commercial bank series, this series includes only payments of $\$ 100$ s from the Federal Reserve Bank of New York, which are generally positive, and omits payments from the Miami and Los Angeles cash offices, which are generally negative and might reflect reflows of currency that moved across U.S. borders through nonbank channels.

Figures 7 through 9 display nominal values, which can be misleading even in a period with relatively low inflation. Figure 10, therefore, displays all of the same series as in Figures 7 through 9, but scaled by the stock of currency in circulation at the end of the previous year, or the approximate percentage-point contribution to currency growth that would be implied by each

of these measures. While the measures certainly vary, they generally point to strong contributions from foreign demand in the early to mid-1990s, a slowing in the mid-2000s, and a resurgence beginning in 2008 .

\section{III.C. Using Cross-Border Flow Estimates to Construct Estimates of the Stock of U.S. Currency Abroad}

While tracking movements in currency in circulation is the major object of operational interest, having an estimate of the stock of U.S. currency abroad is also important for various analytical and operational questions faced by the Federal Reserve. Figures 11A and 11B chart the stocks of currency in circulation implied by the flow measures presented earlier. In Figure $11 \mathrm{~A}$, each line represents the cumulative change in the item since the end of 1988 , when currency in circulation was about $\$ 230$ billion. As indicated by the thicker gray dashed line, total U.S. currency in circulation worldwide has increased by just under $\$ 800$ billion since 1990 . 
The most direct measurement, commercial bank shipments, the solid black line, suggests that \$200 billion has moved abroad since 1990, which would put the total at between $\$ 200$ billion and $\$ 400$ billion, depending on the assumed initial value. The shipments proxy, the solid gray line, suggests that about $\$ 350$ billion moved abroad over the period, putting the total at $\$ 350$ billion to $\$ 550$ billion. ${ }^{25}$ Finally, the adjusted shipments and proxy figures, the dashed black and gray lines respectively, suggest that about $\$ 550$ billion moved abroad over the period, putting the total at $\$ 550$ billion to $\$ 750$ billion. These ranges are, of course, large, though the simple method proposed above in Section III.A.2 produces an estimate very close to the center of the range.

Finally, Figure 11B displays the cumulative flow measurement and estimates as a share of the cumulative increase in currency in circulation at each point in time. Again, the estimates are disparate, but indicate some common trends, including a strong role for international demand in the 1990s, a waning role in the early 2000s, and a resurgence in 2008. In this Figure, as earlier, the role of the former Soviet Union and Argentina is likely understated because of poor data coverage in the shipment data in the early 1990s.

\section{Indirect Estimates of the Share of U.S. Currency}

Earlier work on estimates of the stock of currency abroad has developed and provided estimates from two methods, known as the seasonal method and the biometric method. ${ }^{26}$ Updates to these methods continue to indicate that a substantial share of U.S. currency is abroad, but technical factors and shifting patterns of currency demand have made their use more challenging.

\footnotetext{
${ }^{25}$ The proxy is the only measurement available before 1988. It indicates that $\$ 40$ billion moved abroad over the period from 1974 to 1989; during that time, currency in circulation increased by about $\$ 180$ billion.

${ }^{26}$ Refer to Porter and Judson (1996), Judson and Porter (2001), U.S. Treasury (2006).
} 


\section{IV.A. The Seasonal Method}

\section{IV.A.1. Key Assumptions}

The seasonal method extracts an estimate of the share of U.S. currency abroad by working from four key assumptions. First, we assume that the seasonal pattern in domestic demand for U.S. dollars is similar to the seasonal pattern of demand within Canada for Canadian dollars (similar holidays, vacations, customs, and denominations). More specifically, we assume that the seasonal amplitude, or the percentage difference between the seasonal peak and seasonal trough, is similar for U.S. and Canadian currency demand. ${ }^{27}$ Second, we assume that foreign demand for U.S. dollars has no significant seasonal pattern, or, correspondingly, that the seasonal amplitude for the foreign component of demand for U.S. dollars is zero. Third, we assume that circulation of Canadian dollars outside of Canada is negligible, so that the demand for Canadian dollars can be attributed solely to domestic demand. Finally, we assume that U.S. currency is not used to a substantial degree inside Canada.

\section{IV.A.2. Model}

Based on these assumptions, we can express the seasonal model as follows:

Define:

$\mathrm{S}_{\mathrm{i}}^{\mathrm{j}}=$ seasonal amplitude for country $i$, component $j$

$\beta_{\mathrm{t}}=$ fraction of currency held abroad at time $t$

The overall seasonal amplitude in U.S. currency, $S_{U S}{ }^{T}$, can be expressed as a weighted sum of domestic (d) and foreign (f) components:

$$
\text { (S1) } S_{U S, t}^{T}=\beta_{t} S_{U S, t}^{f}+(1-\beta) S_{U S, t}^{d}
$$

\footnotetext{
${ }^{27}$ Of course, Canadian and U.S. holidays are not identical: to give just two examples, Canada observes Thanksgiving in October and the U.S. observes it in November, and Canada's holidays include the day after Easter and the day after Christmas while these days are not generally holidays in the United States. Nonetheless, the broad outlines of holidays are very similar, especially at a monthly frequency.
} 
We cannot separately identify $S_{U S, t}^{f}$ and $S_{U S, t}^{d}$ but, using the assumptions above, we replace $S_{U S, t}^{f}$ with 0 and $S^{d}{ }_{U S, t}$ with $S_{\text {Can,t }}^{T}$ to obtain:

(S2) $S_{U S, t}^{T}=\beta_{t} * 0+(1-\beta) S_{\text {Can }, t}^{T}$

Or, solving for $\beta_{\mathrm{t}}$

$$
\text { (S3) } \beta_{t}=1-\frac{s_{U S, t}^{T}}{S_{\text {Can }, t}^{T}}
$$

\section{IV.A.3. Application and Estimates}

We estimate the share of all currency abroad and the share of $\$ 100$ s abroad using X-12 ARIMA and an alternative shorter smoothing window to obtain seasonal factors for U.S. and Canadian currency in circulation. Once the seasonal factors are estimated, the seasonal amplitude must be calculated.

In earlier estimates using this method, the peak month was December and the trough month was February of the following year. However, it seems that seasonal factor patterns have changed in the past several years, as illustrated in Figures $12 \mathrm{~A}$ and 12B. December remains the clear peak, though its relative magnitude has varied over time. In particular, February is no longer the trough for U.S. currency in circulation. Rather, September is now the trough, though January seems to track the lower envelope of September and February. Moreover, January's seasonal factor is near the trough for Canada as well.

Because of these shifts over time, I propose three approaches to measuring the seasonal amplitude. For each, I report results using two different seasonal adjustment procedures, X12ARIMA and X12 with a shorter 3x1 smoothing window, shown in black and blue respectively. The first approach estimates the annual amplitude as the difference between the seasonal factor for December of one year and January of the next year. These estimates are associated with the 
year in which December falls and are shown in Figures 13A and 13B as the "annual" estimate, the solid lines. Second, one might choose to fix the months used to calculate the U.S. seasonal amplitude so that they are the same as the months used to calculate the Canadian seasonal amplitude for a given observation. For these "monthly fixed" estimates, shown as the dashed lines, the Canadian seasonal amplitude for a given month is calculated as the difference between the maximum and minimum seasonal factors calculated for the most recent twelve months. The U.S. seasonal amplitude for the same month is calculated as the difference between the seasonal factors in the same months as for the Canadian seasonal amplitude, and the monthly share of currency abroad is then estimated as the trailing average of the estimates for the past twelve months. ${ }^{28} \mathrm{~A}$ third approach is to estimate the seasonal amplitude each month as the difference between the maximum and minimum seasonal factors over the most recent twelve months, and then to estimate the monthly share of currency abroad as the trailing average of the estimates for the past twelve months. The estimates from this approach are shown in Figures 13A and 13B as the "monthly" short-dashed lines.

The results of the seasonal estimates for all currency abroad and for $\$ 100$ s through December 2011 are displayed in Figures 13A and 13B. As was the case in earlier work, these estimates are on the high end of the range. These estimates also show a quite different time series pattern relative to one another as well as relative to other flow-based measures, though the monthly measures generally indicate an upswing in the share of U.S. dollars held abroad.

\footnotetext{
${ }^{28}$ In the last two methods, one could just as easily use the unsmoothed seasonal amplitude estimates. These estimates, though, show a step-function-like shape because the seasonal maximums and minimums generally change once per year. It seems unlikely that the share of currency abroad follows such a step function, and so the moving average imposes a smooth trend. Notably, this averaging does not affect the level of the share estimates on average over time.
} 


\section{IV.B. The Biometric (“Fish”) Method}

\section{IV.B.1. Background: Use for Estimating Wildlife Populations}

The biometric method, also known as the "fish" method, applies a method developed by Petersen (1893) to estimate fish populations to cash processing data to obtain estimates of the "populations" of notes in the United States and the rest of the world. ${ }^{29}$ In the biological application, populations are estimated by capturing some animals, tagging them, releasing them, and then recapturing another sample of animals later. Assuming that both samples are representative, the share of tagged animals in the general population should be the same as the share of tagged animals in the second sample, and the population can thus be estimated. More formally, suppose $M$ animals out of $\mathrm{N}$ total are captured and tagged. Next, suppose that in the second sample, $m$ tagged animals are found out of $n$ captured. Assuming that both samples were representative, the share of tagged animals in the second sample, $m / n$, should be equal to share of all tagged animals, $M$, in the general population, $N$, or $m / n=M / N$. Since $\mathrm{M}$, $\mathrm{m}$, and $\mathrm{n}$ are known, $\mathrm{N}$ can be estimated as $N=(n / m) * M$.

\section{IV.B.2. Application to Estimates of Banknote Populations}

We apply this method to banknotes by using monthly cash processing data from Federal Reserve offices, changes in banknote design, and background information about international banknote shipping patterns. Specifically, we estimate the "population" of notes in the rest of the world by estimating the "population" of notes in the area served by the Federal Reserve Bank cash offices in New York, Los Angeles, and Miami. Although banknotes are not tagged, new designs are introduced from time to time, and processing statistics distinguish between newdesign and old-design notes in some cases.

\footnotetext{
${ }^{29}$ LeCren (1965) notes that Petersen did not use the method for counting but that others properly credit him with the method.
} 
The Federal Reserve introduced new-design \$100 notes in 1991 and in 1996; a further redesign for the $\$ 100$ note has been announced, but the issuance date has not yet been announced. ${ }^{30}$ From the moment each new design was issued, all new banknotes paid out were of the new design. These notes were defined as the "marked" or "tagged" notes. Following the analogy to the biologists' technique, the second sample of notes occurs when notes are returned to the Federal Reserve for processing. Notes returned to Federal Reserve Bank cash offices are authenticated and evaluated for fitness for further use; data on these processing operations are kept by series. ${ }^{31}$ We focus on $\$ 100$ notes here because they are the most significant in dollar value and in the international market.

The assumption that the "marked", or new-series, notes are just as likely to be returned to Federal Reserve offices as older-series notes is quite strong. It is likely more accurate for the 1990-series notes than for the 1996-series notes because the 1996 series was a much more obvious design change: to the extent that dollar users might prefer one series to another, that preference might be stronger for the series with a more significant design change. As with other assumptions, though, the sources of error for this assumption could affect the estimates in either direction: older notes might be underrepresented in Federal Reserve receipts if they are hoarded, or out of active circulation, or they might be overrepresented if dollar users prefer to retain newer notes. ${ }^{32}$ Much more detailed processing data would be needed to analyze these questions.

\footnotetext{
${ }^{30}$ For more information on the earlier changes to U.S. banknote design, refer to Allison and Pianalto (1997).

${ }^{31}$ For operational reasons, it is important for Federal Reserve analysts to be able to assess the longevity and other features of notes by their design or series.

32 The 1990-series notes incorporated microprinting and a security thread but retained the same portrait and the same size and location for the portrait. The 1996-series design changes included a larger portrait moved off the center of the note.
} 


\section{IV.B.3. Adjustments and Updates}

These estimates provide an update as well as some adjustments to previous estimates. The updates currently extend through the end of 2011. The adjustments are the result of corrections to anomalies in the processing data detected in the process of calculating the updates. In particular, recall that a key variable is the share of "tagged", or new-series notes in notes received at Federal Reserve Bank offices. In reviewing the data, we noticed that the processing data for some offices and months implied shares that were anomalous: The values were zero, one, or far away from either values in adjacent months or from values reported by other offices for the same month.

We adjusted the data by identifying anomalous observations and assigning estimated share values. For all offices, a value of zero or one was defined as anomalous. For all but two Federal Reserve Bank cash offices, an office's monthly figure on the share of new-series notes processed was defined as anomalous if the figure was more than one standard deviation above or below the mean processing share reported by all offices for that month. For the remaining two Federal Reserve Bank cash offices, Miami and Los Angeles, observations were defined as anomalous if they were more than three standard deviations above or below the mean processing share for the month. For all offices, the estimated share was assigned the previous month's value for that office.

After these corrections, we estimated the "population" of notes in two "pools", domestic and foreign. The foreign "pool" includes either the New York and Los Angeles offices or the New York, Los Angeles, and Miami cash offices; the domestic "pool” includes all other offices. $^{33}$ In addition, we produce two sets of estimates for the share of notes held abroad, one

\footnotetext{
${ }^{33}$ In the original formulation of this estimate, the foreign pool included only New York and Los Angeles. Subsequent large volumes of activity attributable to international demand prompted the addition of the Miami
} 
using the actual total quantity of notes in circulation, which is known, and one using the estimated total quantity of notes in circulation. By necessity, these estimates are calculated separately for 1990-series and 1996-series notes. Figure 14 displays the estimated share of $\$ 100$ s in circulation abroad for 1990 -series notes, the red dashed line, for 1996-series notes, the blue long-dashed line, and for both types of notes, the solid black line, based on the estimated total stock of notes and based on the assumption that the foreign "pool" is the New York and Los Angeles offices. The estimates using the actual (known) total stock of notes are similar and converge over time, suggesting that the biometric method is better able to estimate the true total quantity of notes in circulation only after the design has been in circulation for a few years. Indeed, as shown in Figure 14A, the biometric method's estimates of total notes in circulation converge to actual figures and remain close.

Because of the timing of the introduction of the series of notes, it is difficult to assess the trend in the share of $\$ 100$ s abroad in the late 1990s, but both sets of estimates show a general decline in the share of $\$ 100$ s abroad beginning in the late 1990 s, from somewhere between 65 and 72 percent to a bit under 58 percent by about 2007. As in the flow data, the biometric method indicates a sharp turnaround in late 2008; this method now indicates that about 62 percent of $\$ 100$ notes were in circulation abroad at the end of 2011. Estimates using the New York, Los Angeles, and Miami offices as the foreign pool are about 5 to 10 percentage points lower; however, as with the shipment flows discussed earlier, it is difficult to know how to interpret consistently negative inflow data.

Estimates using this method for $\$ 50$ notes indicate similar patterns over time with somewhat lower shares abroad — about 40 percent at the end of 2011 . When combined with the

office to this group. The estimate based on just the New York and Los Angeles offices is analogous to the adjustment commercial bank shipments estimate: it assumes that receipts at the Miami office reflect unmeasured outflows and assigns a net value of zero. 
estimates for $\$ 100$ s, these estimates suggest that about $\$ 510$ billion, or just over half of all U.S. currency in circulation was held abroad at the end of 2011: about $\$ 480$ of the $\$ 780$ billion in $\$ 100$ s and about $\$ 30$ billion of the $\$ 70$ billion in $\$ 50$ s in circulation.

\section{Estimating a Currency Demand Function}

Finally, we return to the idea of a currency demand function, which was briefly explored in Section 3 with reference to Canada. Here, the approach is to specify a demand function for U.S. currency that allows for foreign shipments as well as domestic factors. Our general assumption has been that currency demand consists of two components: a domestic component, which should be correlated with the typical determinants of money demand; and an international component, which is driven by routine as well as crisis-related fluctuations in foreign demand for U.S. currency.

Table 1 presents coefficient estimates for a simple error correction model for the currency component of M2 estimated quarterly beginning in 1988, a date chosen for two reasons. ${ }^{34}$ First, 1988 marks the beginning of availability of the commercial bank shipment data as well as an apparent upshift in international demand for U.S. currency. Second, preliminary testing (not shown) indicates a distinct structural break in 1988. The regression model consists of two equations, one for the steady state and one for dynamics.

\footnotetext{
${ }^{34}$ As noted in Section III.B., the currency component of M2 excludes currency held in the vaults of depository institutions, or vault cash, which was one of the most volatile components of currency in circulation just before and after the century date change. Thus, this measurement of currency is more useful for longer-term analysis where the inclusion of the large and transitory swings in vault cash might be inordinately influential, such as in quarterly measurements where the periods immediately before and immediately after the century date change fall into different quarters.
} 
The steady state equation is

$$
\log (N G D P)-\log (\text { Curr })=\alpha_{0}+\alpha_{1}\left(R_{\text {short }}\right)+\alpha_{2} \text { Trend }-\varepsilon_{t}
$$

The dynamic equation is

$$
\begin{aligned}
d(\log (\text { Curr })) & =\beta_{0} \varepsilon_{t-1}+\beta_{1} S H I P+\beta_{2}\left(d(\log (\text { Curr }))_{t-1}+\beta_{3} d\left(\log (N G D P)_{t-1}\right.\right. \\
& +\beta_{4} d(\log (N G D P))_{t-4}+\beta_{5} Y 2 K+v_{t}
\end{aligned}
$$

Table 1: Quarterly Error Correction Regression Results

\begin{tabular}{|c|c|c|}
\hline & Coefficient & T-Stat \\
\hline \multicolumn{3}{|l|}{ Steady - state equation } \\
\hline$\alpha_{0}($ Constant $)$ & 3.548 & 14.7 \\
\hline$\alpha_{1}\left(\mathrm{R}_{\text {short }}\right)$ & 0.037 & 2.1 \\
\hline$\alpha_{2}$ (Trend) & -0.003 & -3.0 \\
\hline \multicolumn{3}{|l|}{ Dynamic equation } \\
\hline$\beta_{0}$ (Error correction coefficient) & -0.026 & -2.1 \\
\hline$\beta_{1}$ (Shipments) & 0.531 & 8.1 \\
\hline$\beta_{2}$ (Y2K Dummy) & 0.003 & 0.9 \\
\hline$\beta_{3}\left(d(\log (\text { Curr }))_{t-1}\right.$ & 0.539 & 9.7 \\
\hline$\beta_{4} d(\log (N G D P))_{t-1}$ & 0.220 & 3.9 \\
\hline$\beta_{5} \mathrm{~d}(\log (N G D P))_{\mathrm{t}-4}$ & 0.241 & - \\
\hline \multicolumn{3}{|l|}{ Adjusted R-squared $=0.70$} \\
\hline Number of obs $=96$ & & \\
\hline
\end{tabular}
Dependent variable: Growth of seasonally adjusted currency component of M2

Quarterly, 1988:1 - 2011:4

The variables are defined as follows:

- NGDP: Nominal GDP, seasonally adjusted

- Curr: Seasonally adjusted currency component of M2

- SHIP: Two-month moving average of commercial bank shipments adjusted for negative net shipments, divided by the previous period's seasonally adjusted currency component of M2. This formulation puts shipments on the same basis as the monetary aggregate growth data, which are calculated as monthly averages.

- Rshort: Short-term interest rate, a proxy for the opportunity cost of holding currency

- Trend: 1 for 1988:Q1 and increasing by 1 each quarter 
- Y2K: Dummy: 1 for 1999:Q4 and -1 for 2000:Q1

The coefficients in the steady state equation are constrained to unitary elasticity, and the coefficients on the lagged values of log changes in currency and GDP are constrained to sum to 1. The equations are estimated by nonlinear least squares in one step by substituting for the error term in the dynamic equation. After controlling for the estimated contribution of overseas demand, the coefficients are generally of the expected sign and magnitude. The short interest rate is positively correlated with velocity, the error correction coefficient is negative, shipments are strongly significant, and recent lags of currency growth and income are significant. The time trend coefficient is somewhat counterintuitive, but its overall contribution is small and so we leave further examination of it for future work.

Figure 15A displays overall currency growth, the solid black line, the proxy measurement, the short-dashed red line, and nominal GDP growth, the dashed gray line, for the regression sample period. Finally, Figures $15 \mathrm{~B}$ and $15 \mathrm{C}$ display the quarterly and cumulative contributions to currency growth from foreign demand implied by the regression in Table 1 . In both figures, the contributions are calculated from dynamic forecasts with residuals applied equally to the two components. As indicated by the dashed red line in Figure 15C, international shipments, as measured by the $\$ 100$ s proxy, are responsible for about two thirds of the growth in currency over this period.

Notably, even the highest of these estimates suggests that currency holdings by U.S. residents are significant—at least $\$ 1,000$ per person—a finding at odds with survey work on currency holdings. ${ }^{35}$ Feige $(1996,2012)$ suggests that underground economic activity could

\footnotetext{
${ }^{35}$ The most recent Survey of Consumer Payment Choice, conducted in 2009, indicates holdings of less than $\$ 100$ per person (Foster et al., 2011).
} 
account for this discrepancy, though underreporting, especially by individuals with large cash holdings, is also likely a substantial problem.

\section{Summary, Conclusions, and Directions for Future Work}

In sum, much as in earlier work, the currently available data do not allow for precise estimates of foreign holdings of U.S. currency, and the available estimates are somewhat disparate. Nonetheless, direct measurements, regression-based estimates, and indirect estimates all point to strong international demand in the 1990 s, a falloff in the early 2000 s, and a recent resurgence that coincided with the collapse of Lehman Brothers. ${ }^{36}$ Collectively, these methods suggest that half or a bit more than half of U.S. currency circulates abroad.

There are many promising avenues for future investigation, including the following. For the biometric method, what might we be able to learn about hoarding of notes? Will biometric estimates change when the new $\$ 100$ note is issued? For the seasonal method, what is the significance, if any, of the shift observed in seasonal patterns of demand for U.S. currency? For the regression-based methods, would a more rigorous and sophisticated regression framework yield more precise or very different estimates? Finally, are there quantifiable indicators of market tension that show a systematic relationship with external demand for U.S. dollars, and can any of those indicators be forecasted? Some work along these lines shows promise, but is in the early stages. $^{37}$

\footnotetext{
${ }^{36}$ Indeed, weekly data, reported in Appendix Figure 2, show an unmistakable turnaround in demand patterns in the middle of September 2008.

${ }^{37}$ Thus far, analysis along these lines has appeared only in internal Federal Reserve documents.
} 


\section{Appendix: Currency data sources and definitions}

Several agencies and publications carry data on U.S. currency in circulation, and several additional sources are available internally in the Federal Reserve. The publications and the level of detail provided by each source are summarized in table 1. None of these sources provides any information about domestic and international movements of U.S. currency.

\begin{tabular}{|c|c|c|c|c|c|c|}
\hline \multicolumn{7}{|c|}{ Appendix Table 1: Public data sources on U.S. currency in circulation } \\
\hline $\begin{array}{l}\text { Publication } \\
\text { name }\end{array}$ & Source & URL & Frequency & Date Range & Definition & $\begin{array}{l}\text { By denom- } \\
\text { ination? }\end{array}$ \\
\hline H.4.1 & $\begin{array}{l}\text { Federal } \\
\text { Reserve }\end{array}$ & http://www.federalreserve.gov/ & $\begin{array}{l}\text { Weekly average } \\
\text { and Wednesday }\end{array}$ & $\begin{array}{l}\text { 1914; Time } \\
\text { series data } \\
\text { online starting } \\
\text { in December } \\
2002 .\end{array}$ & $\begin{array}{l}\text { Table 1: Currency } \\
\text { in circulation } \\
\text { Tables } 9 \text { and 10: } \\
\text { Federal Reserve } \\
\text { notes, net }\end{array}$ & No \\
\hline H.6 & $\begin{array}{l}\text { Federal } \\
\text { Reserve }\end{array}$ & $\begin{array}{l}\text { http://www.federalreserve.gov/ } \\
\text { releases/h6/ }\end{array}$ & Weekly average & 1989-present & $\begin{array}{l}\text { Currency } \\
\text { component of the } \\
\text { money stock }\end{array}$ & No \\
\hline $\begin{array}{l}\text { Treasury } \\
\text { Bulletin }\end{array}$ & Treasury & $\begin{array}{l}\text { http://www.fms.treas.gov/ } \\
\text { bulletin/index.html }\end{array}$ & Quarter-end & Current year & $\begin{array}{l}\text { All types of } \\
\text { currency } \\
\text { outstanding, held } \\
\text { by the Treasury } \\
\text { and Federal } \\
\text { Reserve, and in } \\
\text { circulation. }\end{array}$ & Yes \\
\hline
\end{tabular}




\begin{tabular}{|c|c|c|c|c|c|c|}
\hline \multicolumn{7}{|c|}{ Appendix Table 1: Public data sources on U.S. currency in circulation } \\
\hline $\begin{array}{c}\text { Publication } \\
\text { name }\end{array}$ & Source & URL & Frequency & Date Range & Definition & $\begin{array}{l}\text { By denom- } \\
\text { ination? }\end{array}$ \\
\hline $\begin{array}{l}\text { Annual } \\
\text { Report }\end{array}$ & $\begin{array}{l}\text { Federal } \\
\text { Reserve }\end{array}$ & $\begin{array}{l}\text { http://www.federalreserve.gov/ } \\
\text { boarddocsfs/rptcongress/ } \\
\text { default.htm\#ar }\end{array}$ & $\begin{array}{l}\text { Annual. } \\
\text { Data are reported } \\
\text { for month-end and } \\
\text { month average for } \\
\text { previous year and } \\
\text { year-end and year } \\
\text { average for earlier } \\
\text { years. }\end{array}$ & 1914-present & & No \\
\hline $\begin{array}{l}\text { Z.1 (Flow of } \\
\text { Funds) }\end{array}$ & $\begin{array}{l}\text { Federal } \\
\text { Reserve }\end{array}$ & $\begin{array}{l}\text { http://www.federalreserve.gov/ } \\
\text { releases/z1/ }\end{array}$ & Quarter-end & 1996-present & $\begin{array}{l}\text { Currency in } \\
\text { circulation }\end{array}$ & \\
\hline $\begin{array}{l}\text { Banking } \\
\text { and } \\
\text { Monetary } \\
\text { Statistics } \\
\text { and Annual } \\
\text { Statistical } \\
\text { Supplement } \\
\text { (various } \\
\text { years) }\end{array}$ & $\begin{array}{l}\text { Federal } \\
\text { Reserve }\end{array}$ & http://fraser.stlouisfed.org/ & $\begin{array}{l}\text { Weekly average } \\
\text { and Wednesday; } \\
\text { monthly average } \\
\text { and month-end; } \\
\text { Annual average } \\
\text { and year-end }\end{array}$ & $1914-1990$ & $\begin{array}{l}\text { Currency in } \\
\text { circulation }\end{array}$ & $\begin{array}{l}\text { Yes, for } \\
\text { selected } \\
\text { dates. }\end{array}$ \\
\hline Online & $\begin{array}{l}\text { Federal } \\
\text { Reserve }\end{array}$ & $\begin{array}{l}\text { http://www.federalreserve.gov/ } \\
\text { paymentsystems/coin_data.htm }\end{array}$ & Annual, year-end & 1990-present & $\begin{array}{l}\text { Paper currency } \\
\text { (Federal Reserve } \\
\text { notes, U.S. notes, } \\
\text { and currency no } \\
\text { longer issued) }\end{array}$ & Yes \\
\hline
\end{tabular}




\section{References}

Allison, Theodore E., and Rosanna S. Pianalto (1997), “The Issuance of Series-1996 \$100 Federal Reserve Notes: Goals, Strategies, and Likely Results," Federal Reserve Bulletin, vol. 83 (July), pp. 557-64.

Banco de Mexico (2012), Annual Report. http://www.banxico.org.mx/publicaciones-ydiscursos/publicaciones/informes-periodicos/anual/index-en.html

Bank for International Settlements (2012). Statistics on payment, clearing and settlement systems in the CPSS countries: Figures for 2010. http://www.bis.org/publ/cpss99.pdf

Feige, Edgar L. (1996), "Overseas Holdings of U.S. Currency and the Underground Economy," in Susan Pozo, ed., Exploring the Underground Economy: Studies of Illegal and Unreported Activity, Kalamazoo, Mich.: W.E. Upjohn Institute for Employment Research, pp. 5-62.

Feige, Feige (2012), “New estimates of U.S. currency abroad, the domestic money supply and the unreported economy," Crime, Law and Social Change, vol. 57:3 (April 2012).

Foster, Kevin, Erik Meijer, Scott Schuh, and Michael Zabek (2011), “The 2009 Survey of Consumer Payment Choice," Federal Reserve Bank of Boston Discussion Paper 11-1.

Hellerstein, Rebecca, and William Ryan (2011), "Cash Dollars Abroad," Federal Reserve Bank of New York Reports, no. 400. February 2011.

Judson, Ruth A., and Richard D. Porter (2001), “Overseas Dollar Holdings: What Do We Know?" Wirtschaftspolitische Blatter, vol. 4.

Judson, Ruth A., and Richard D. Porter (2010), "Estimating the Volume of Counterfeit U.S. Currency in Circulation Worldwide: Data and Extrapolation," Federal Reserve Bank of Chicago Policy Discussion Series PDP 2010-2.

Kamin, Steven B., and Neil R. Ericsson, "Dollarization in post-hyperinflationary Argentina," Journal of International Money and Finance 22 (2003), pp. 195-211.

LeCren, E.D. (1965), “'A Note on the History of Mark-Recapture Population Estimates,'” The Journal of Animal Ecology, vol. 34 (June 1965), pp. 453-54

Petersen, C.G. Joh. (1893), "'On the Biology of Our Flat-Fishes and on the Decrease of Our FlatFish Fisheries," Report of the Danish Biological Station, vol. 4, 1893.

Porter, Richard D. (1993), "Estimates of Foreign Holdings of U.S. Currency-An Approach Based on Relative Cross-Country Seasonal Variations," in Nominal Income Targeting with the Monetary Base as Instrument: An Evaluation of McCallum's Rule, Finance and Economics Discussion Series Working Study 1 (Board of Governors of the Federal Reserve System, March). 
(1993), "Foreign Holdings of U.S. Currency," International Economic Insights (November/December), p. 5.

_ and Ruth A. Judson (1996), "The Location of U.S. Currency: How Much is Abroad?" Federal Reserve Bulletin, vol. 82 (October), pp. 883-903.

U.S. Census Bureau (2011), Statistical Abstract of the United States 2012. Washington DC: U.S. Government Printing Office.

U.S. Treasury (2006). The Use and Counterfeiting of U.S. Currency Abroad, Part III. Washington DC: U.S. Department of the Treasury. 
Figure 1A: U.S. Currency Levels, 1989-2011

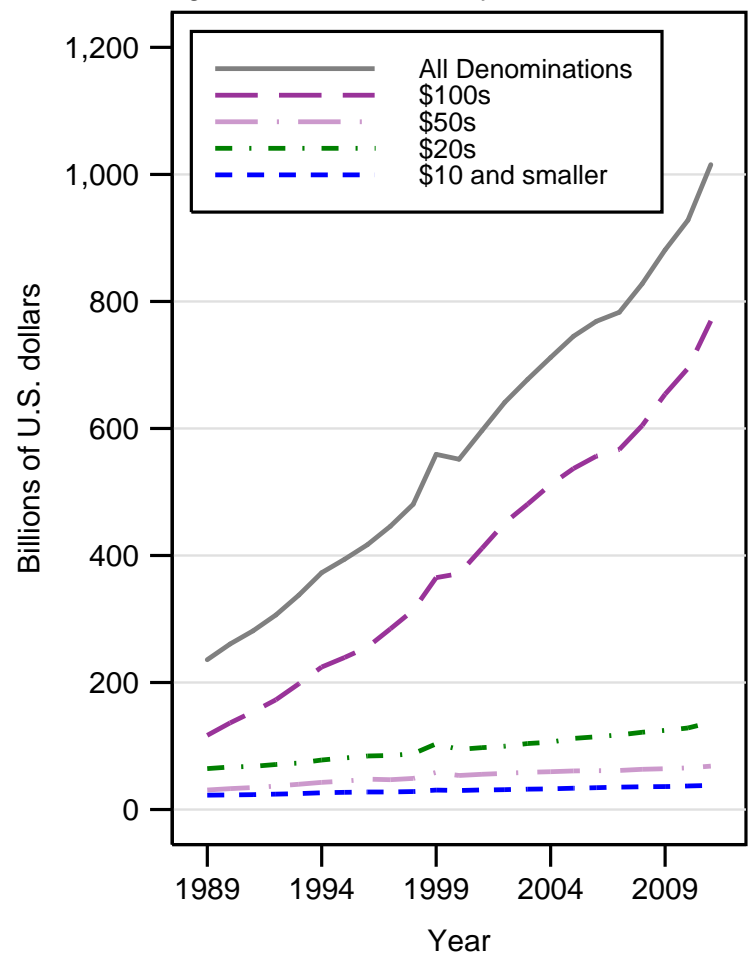

Note. Average of Sept. and Dec. currency in circulation.

Figure 2A: Canadian Currency Levels, 1989-2011

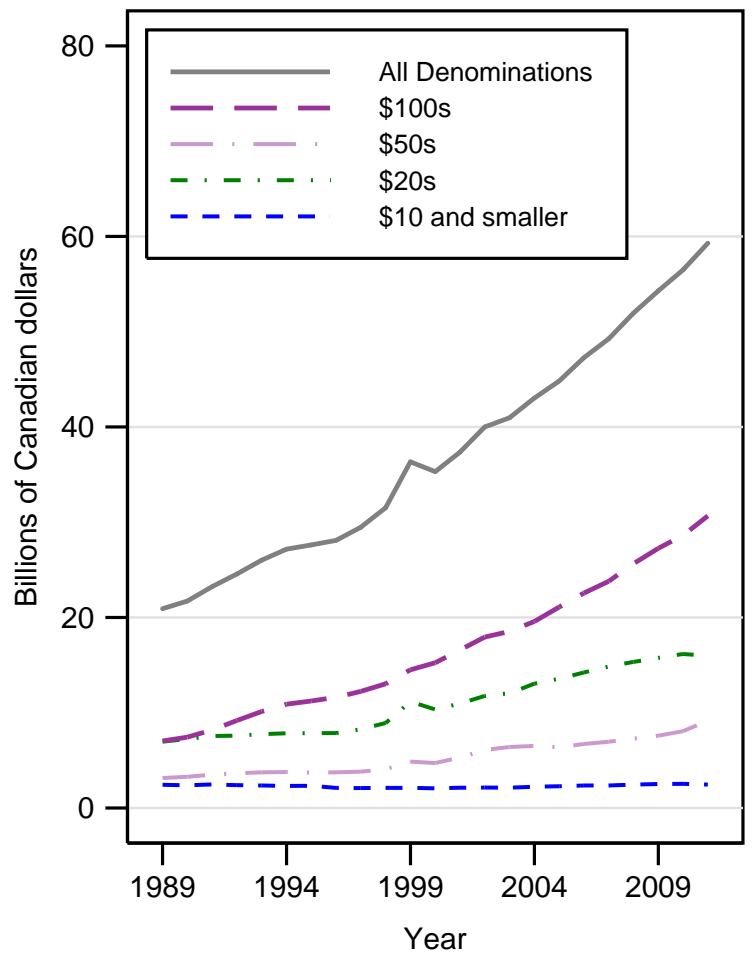

Note. Average of Sept. and Dec. currency in circulation.
Figure 1B: Annual Growth of U.S. Currency, 1989-2011

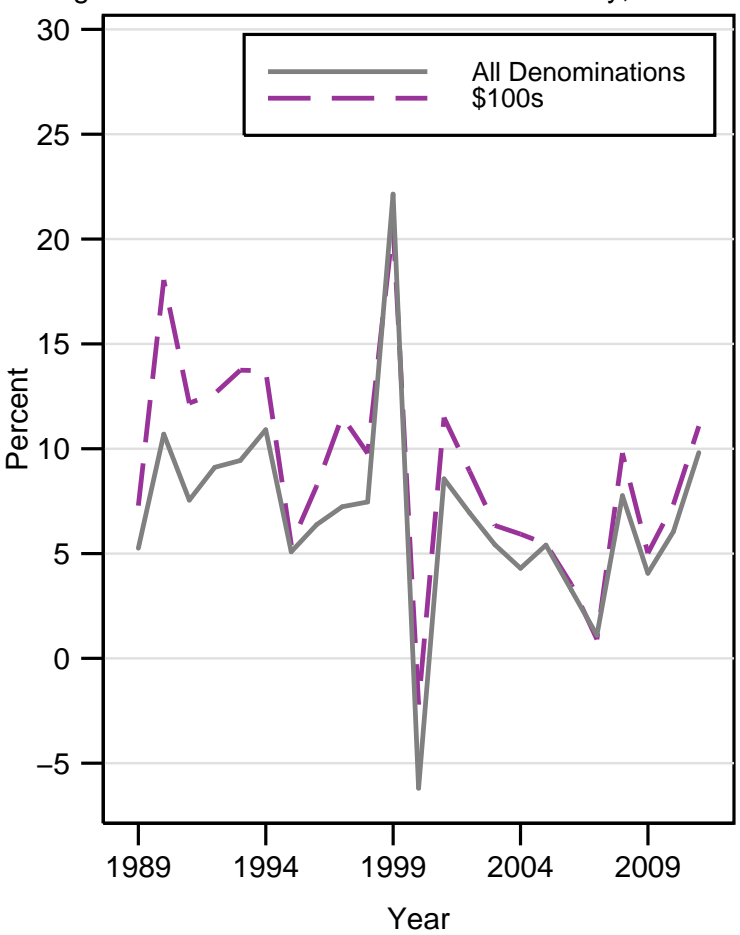

Note. Annual growth rates of fourth-quarter averages (average of end-September and end-December levels).

Figure 2B: Annual Growth, Canadian Currency, 1989-2011

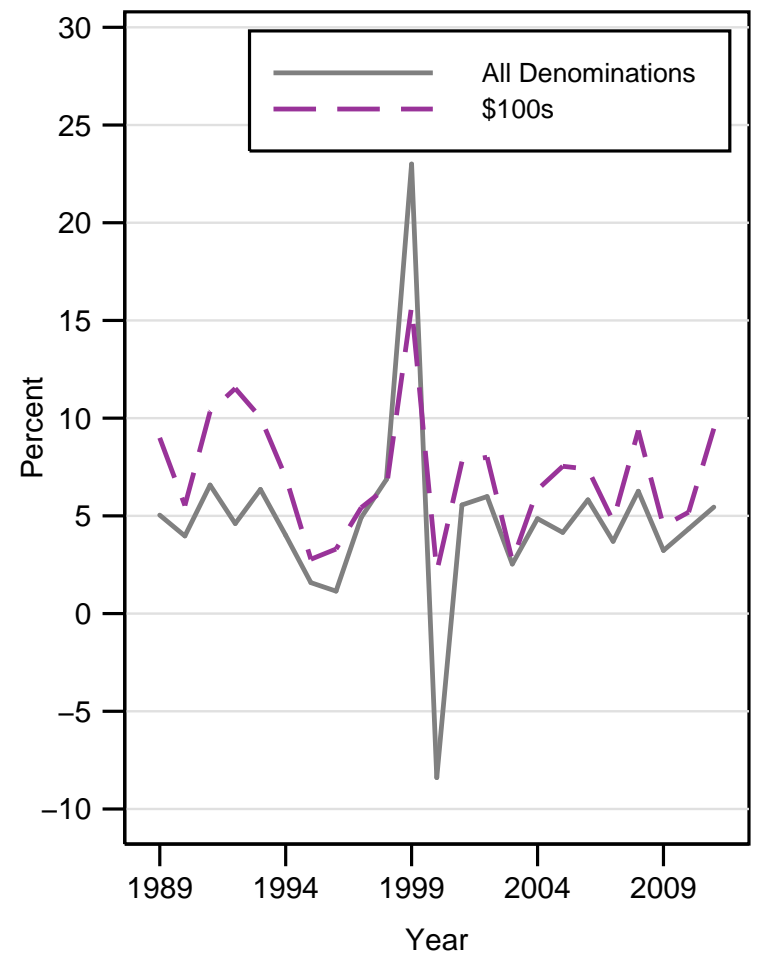

Note. Annual growth rates of fourth-quarter averages. 
Figure 3: U.S. Currency to Nominal GDP Ratios, 1960-2011

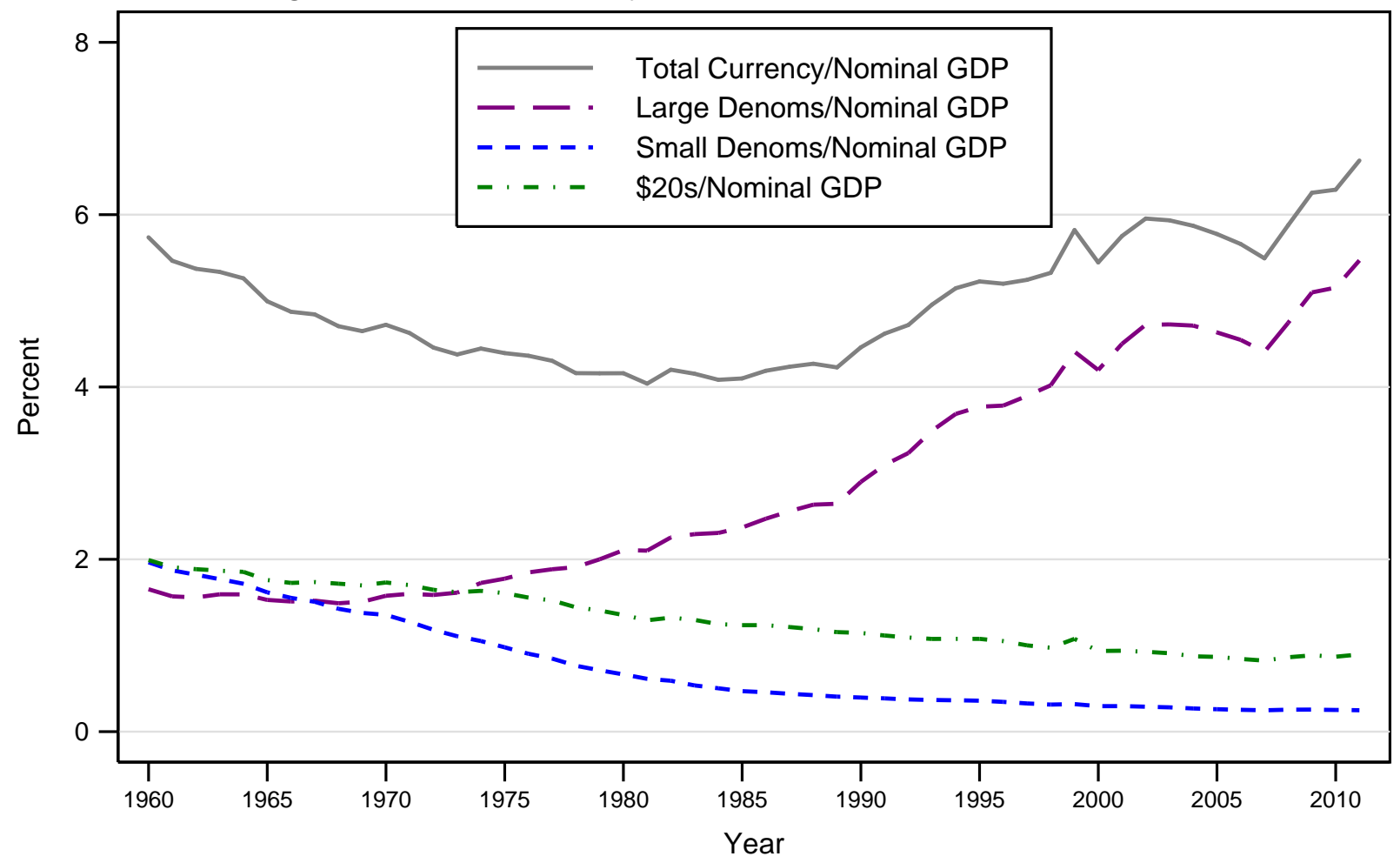

Figure 4: Canadian Currency to Nominal GDP Ratios, 1960-2011

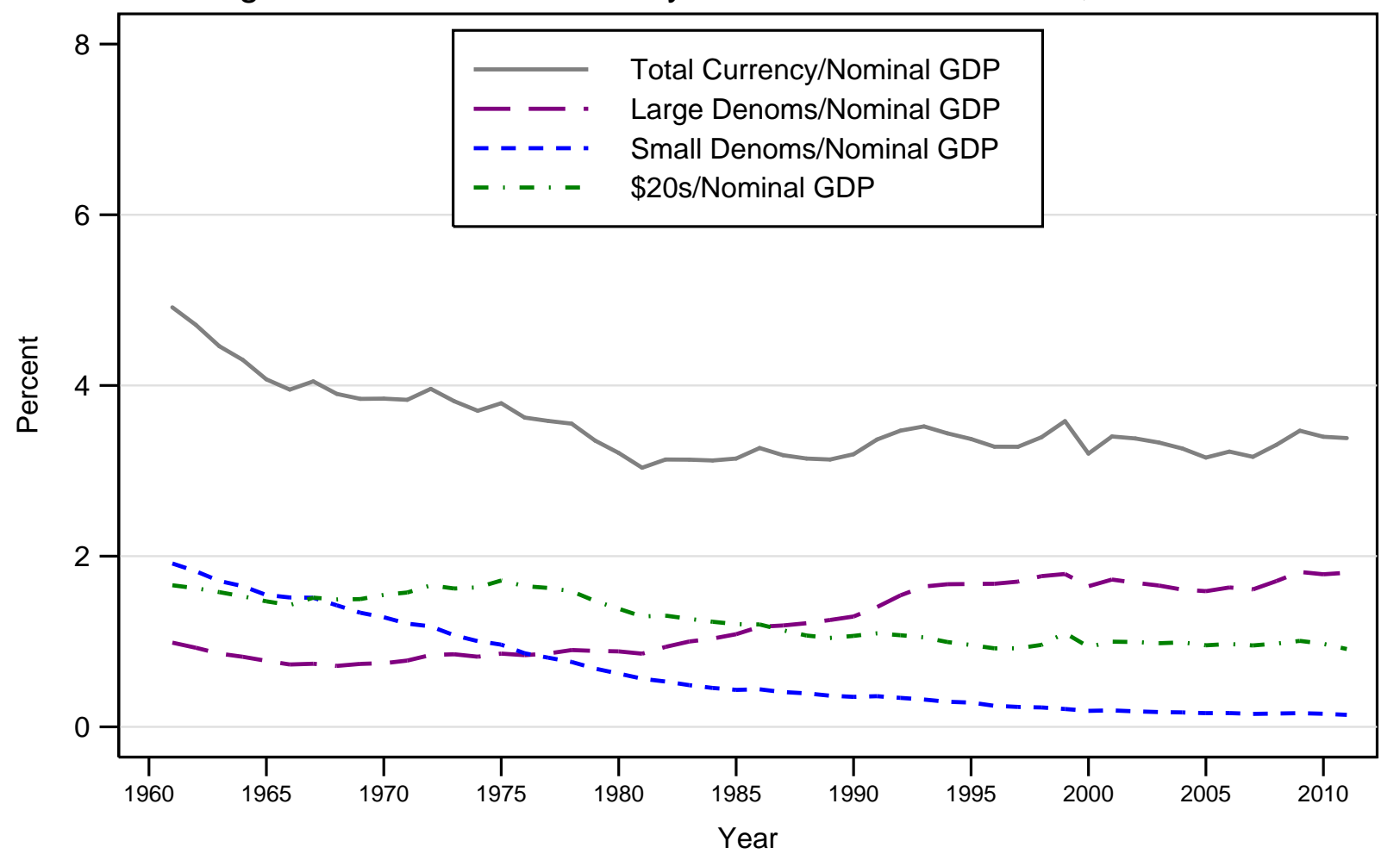


Figure 5: Growth Rates of U.S. and Canadian Nominal GDP, 1960-2011

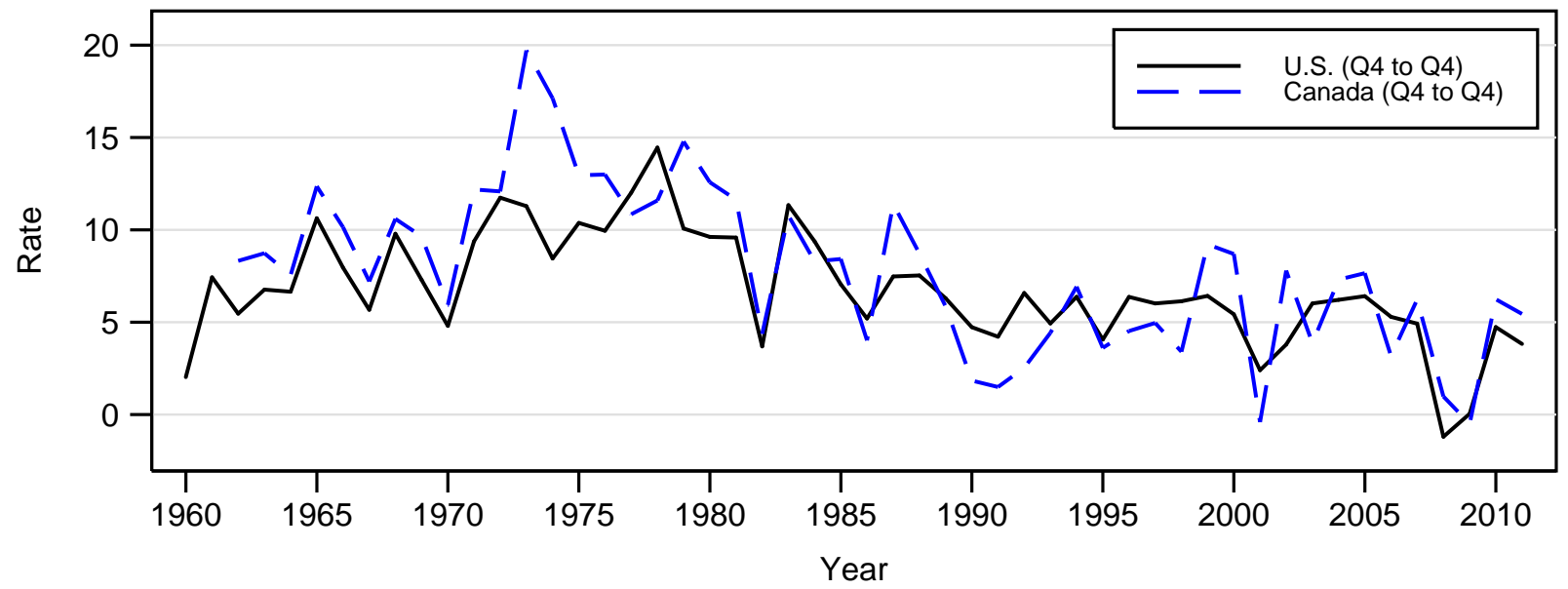

Figure 6A: Simple Estimates of the Share of U.S. Currency Abroad

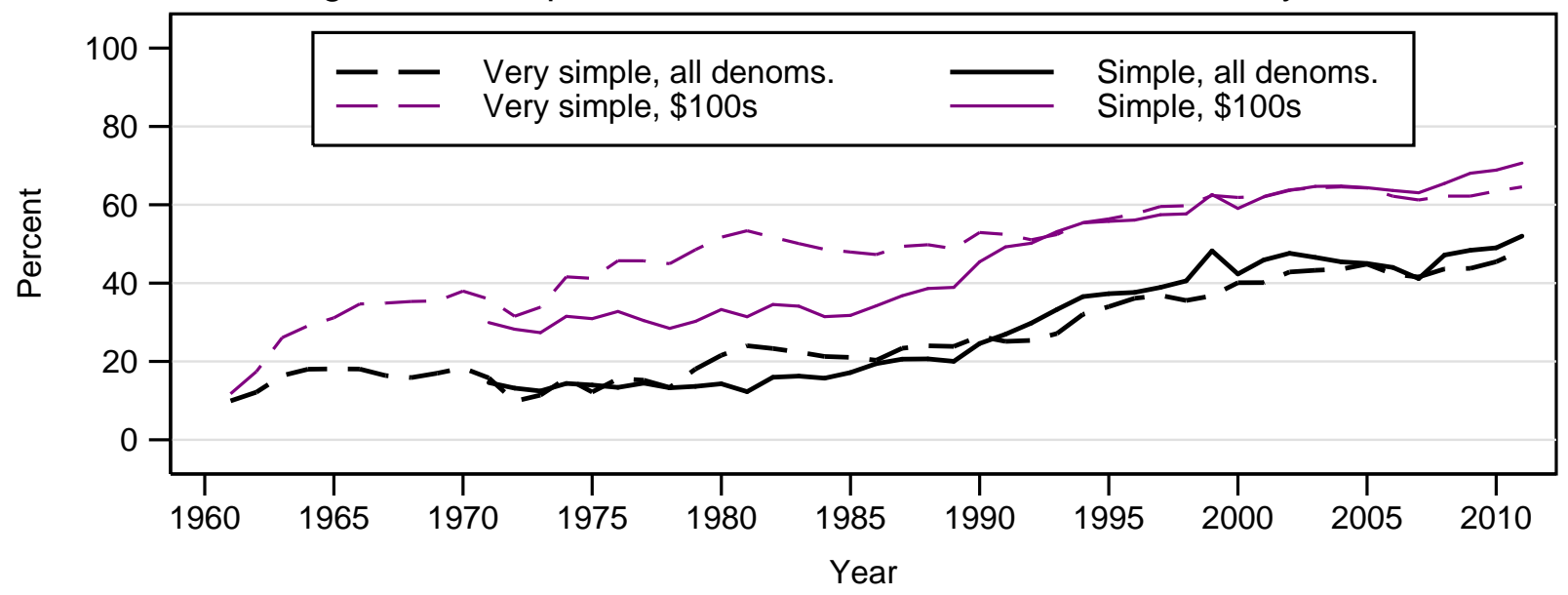

Figure 6B: Simple Estimates of the Value of U.S. Currency Abroad

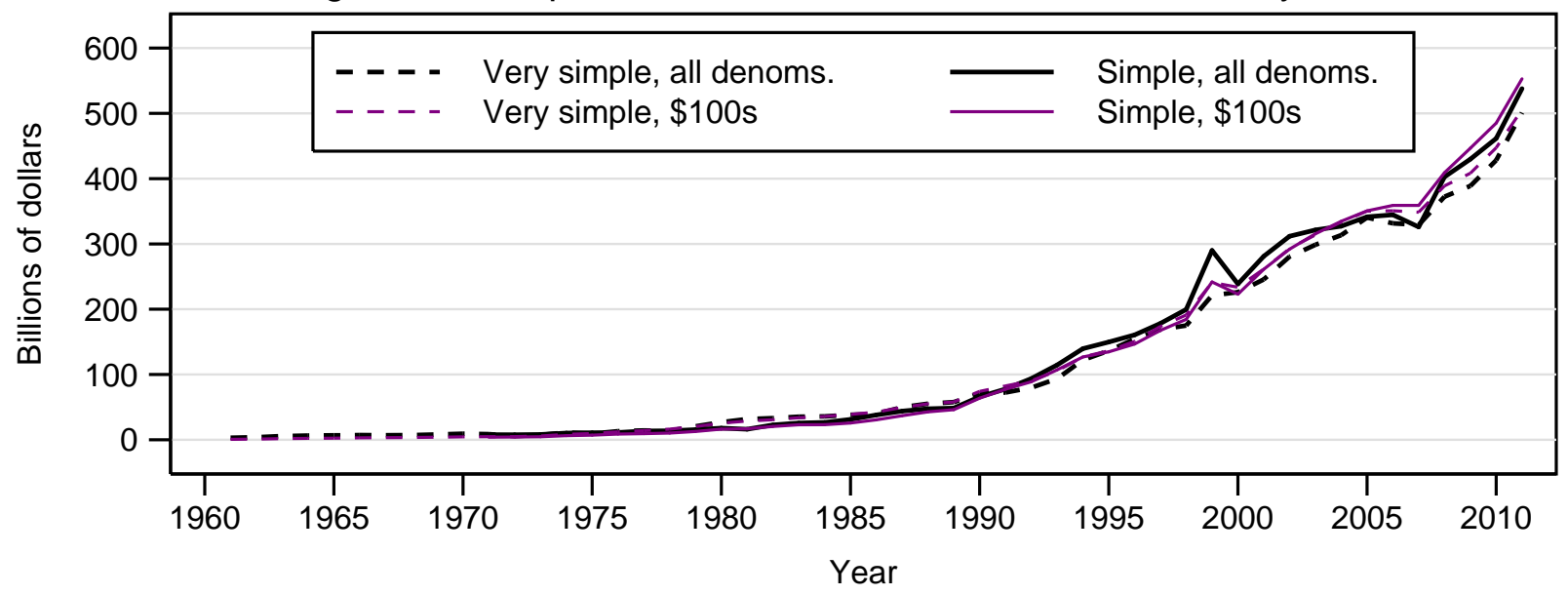


Figure 7: International Commercial Bank Shipments And Total Change in U.S. Currency Flows Abroad

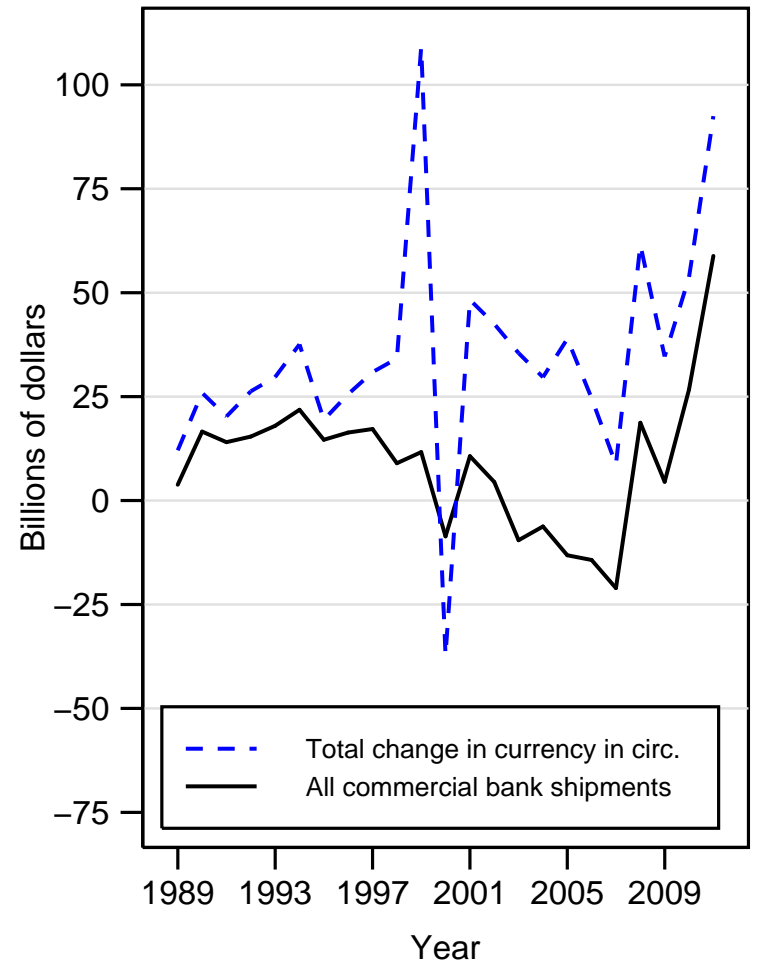

Figure 9: Total Shipments, the Shipment Proxy, And Adjusted Shipments

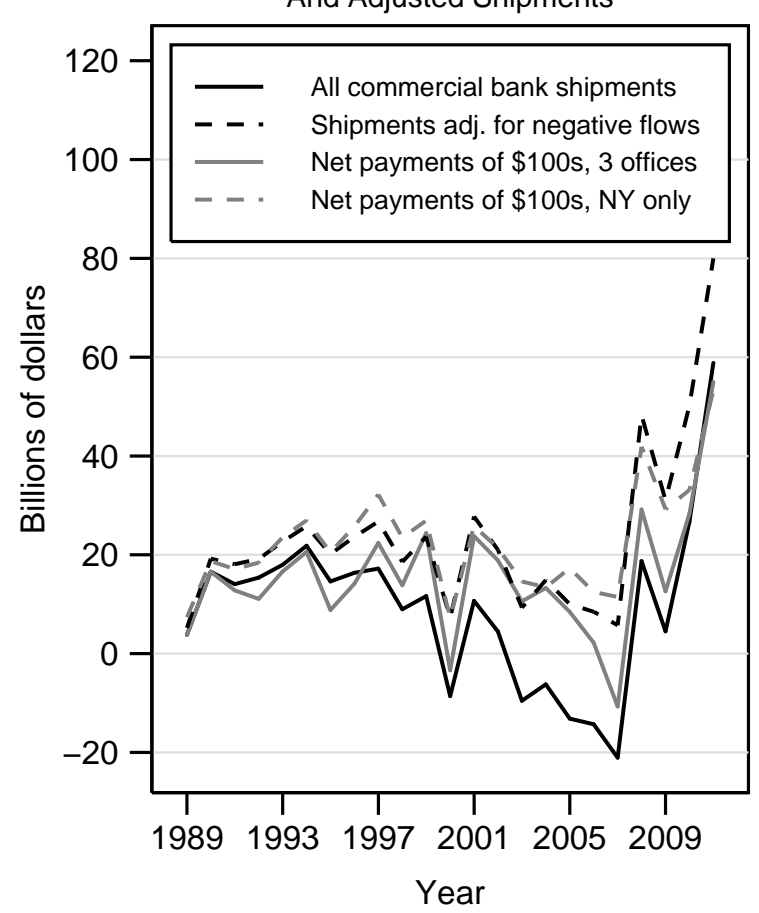

Note: The gray solid line in Figures 9 and 10 indicates net payments of $\$ 100$ s from NY, LA, and Miami.
Figure 8: Total Commercial Bank Shipments and Shipments Selected Group of Countries

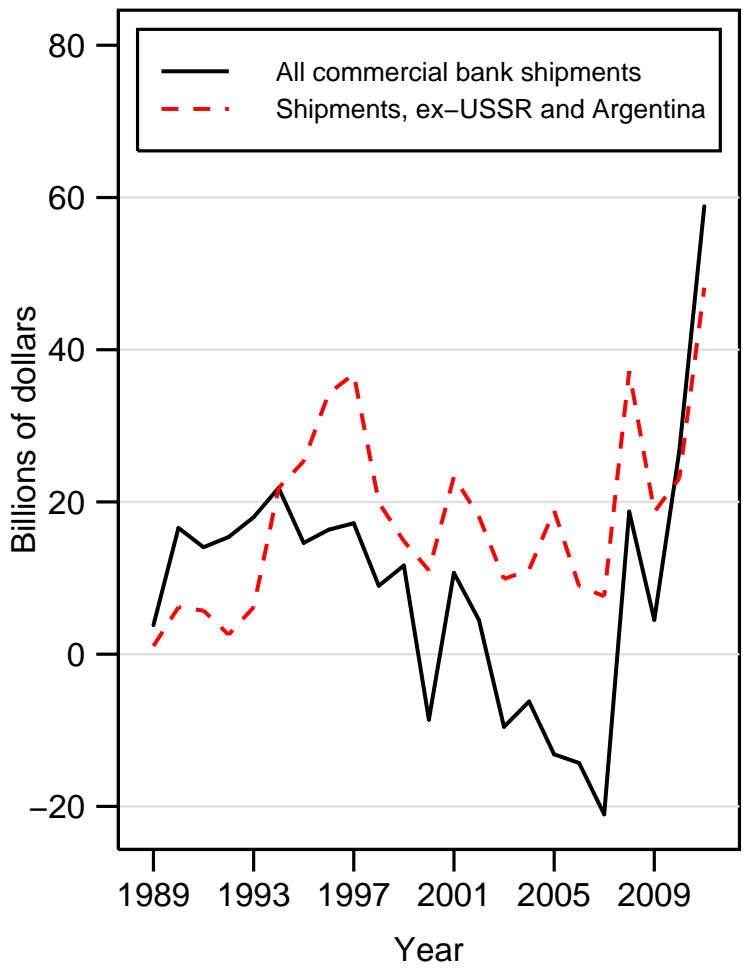

Figure 10: Flows of U.S. Currency Shipped Abroad Relative to Currency in Circulation

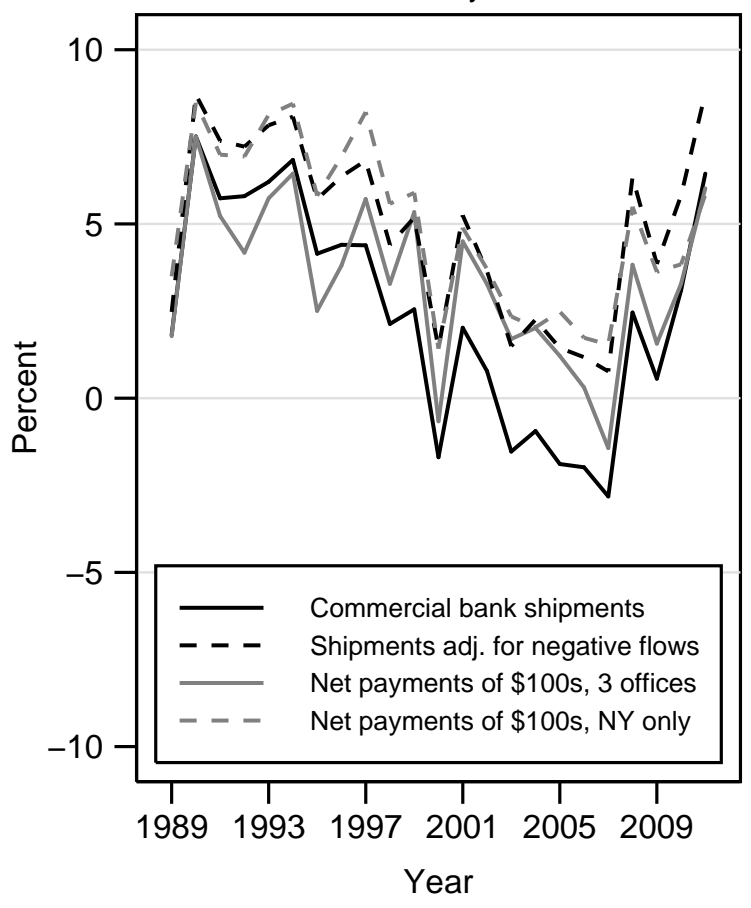

Note: Annual totals divided by currency in circulation at end of previous year. 
Figure 11A: Measures of Cumulative Flows of U.S. Currency Abroad, 1989-2011

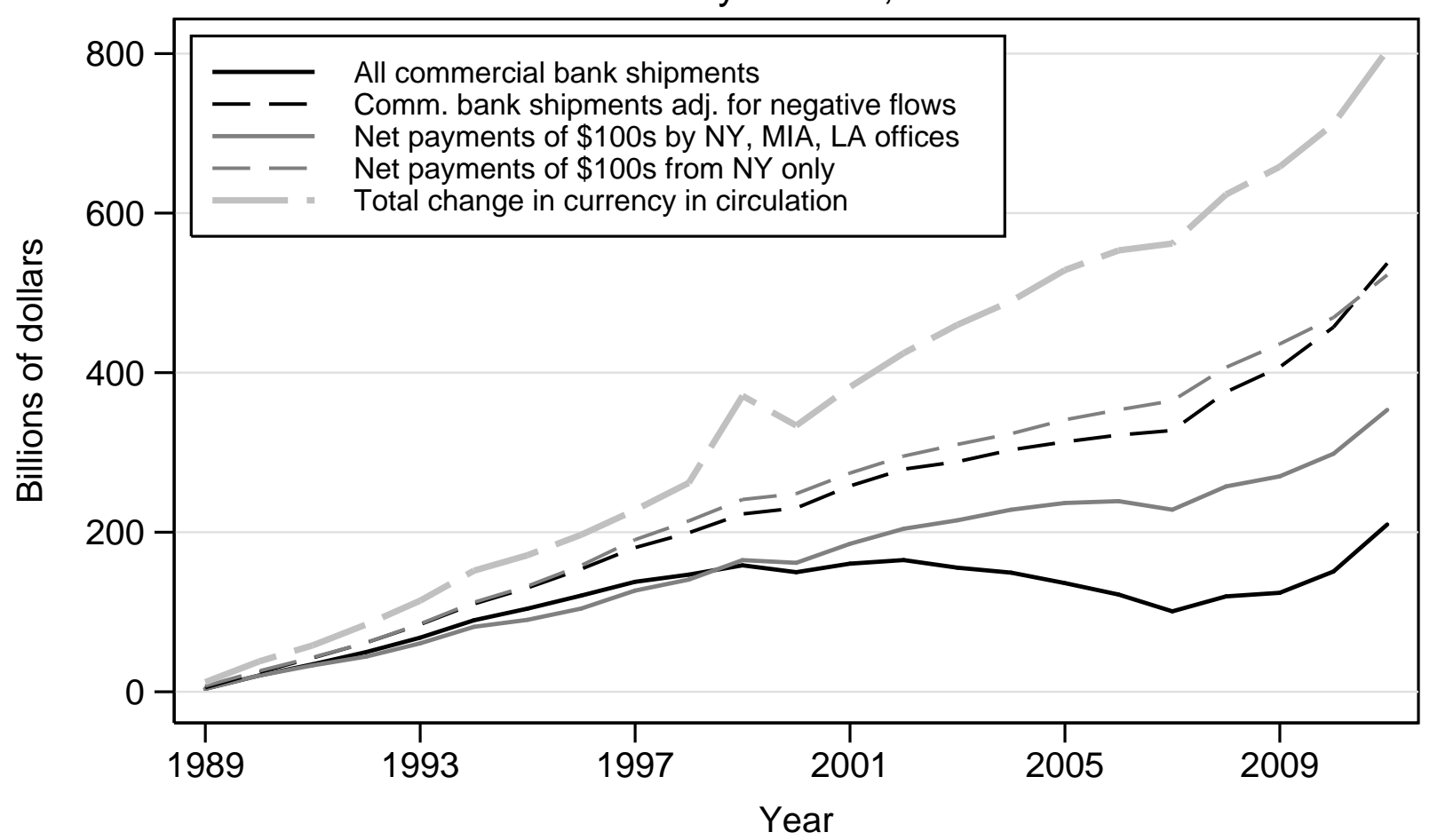

Figure 11B: Cumulative Flows of U.S. Currency Shipped Abroad Relative to Cumulative Changes in Currency in Circulation, 1989-2011

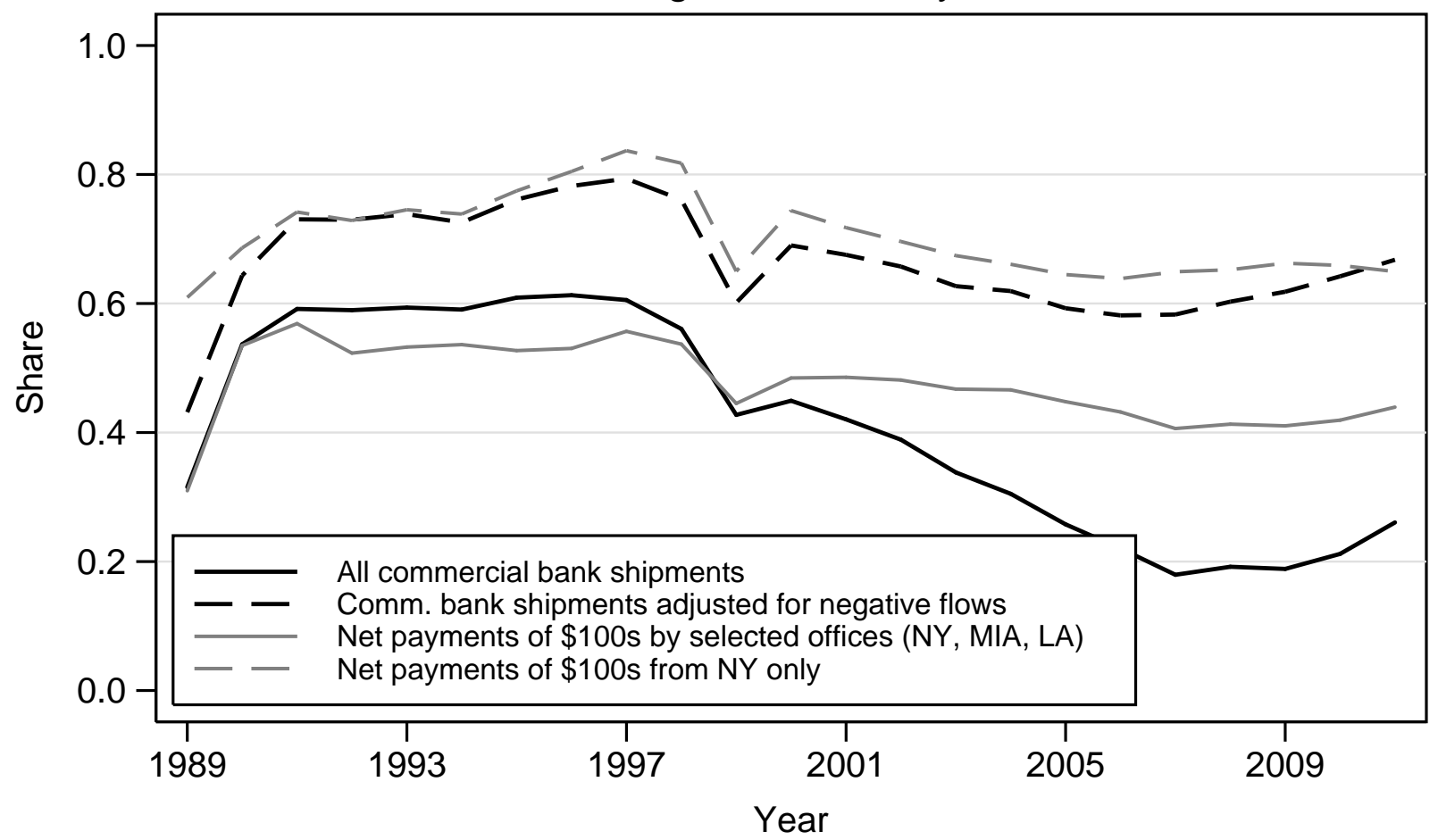


Figure 12A: X-12 Seasonal Factor Estimates Total U.S. Currency in Circulation

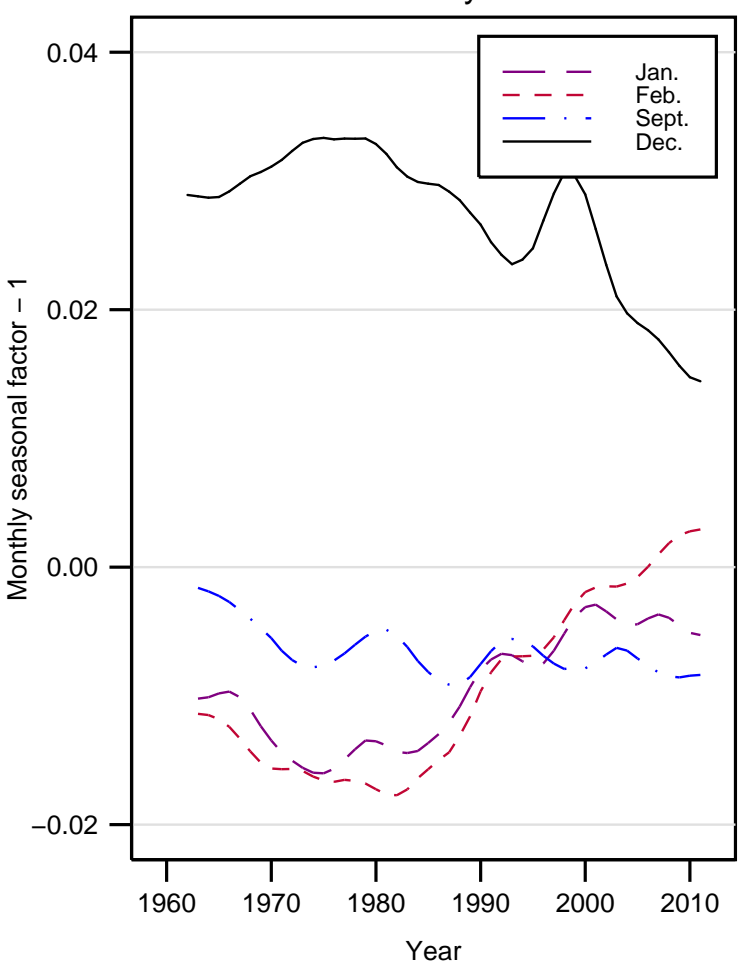

Figure 13A: Seasonal Method Estimated Share of All U.S. Currency Abroad

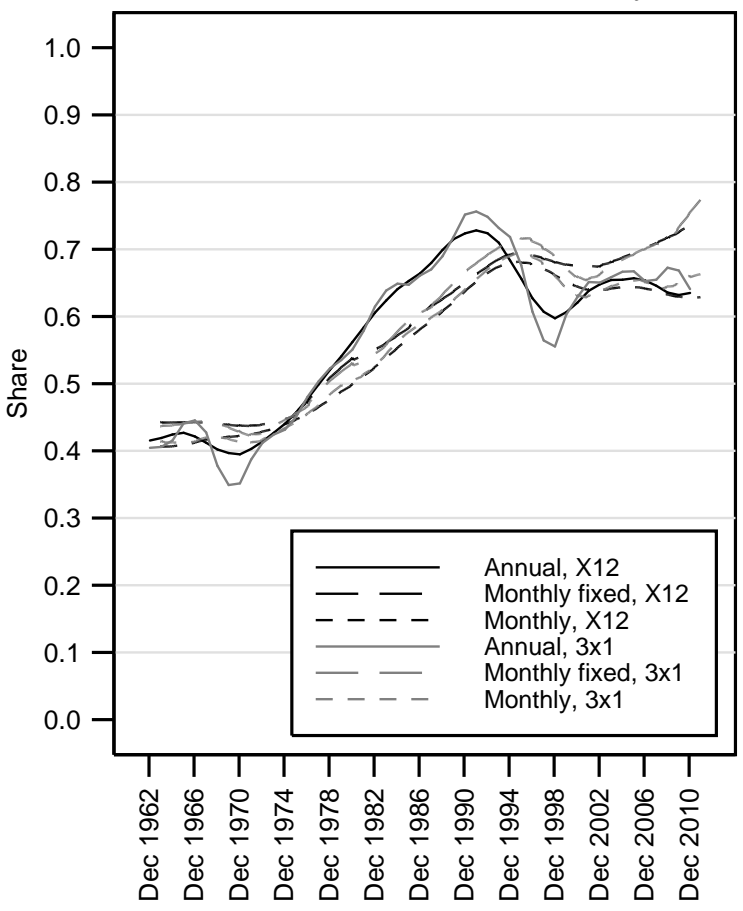

Month
Figure 12B: X-12 Seasonal Factor Estimates Total Canadian Currency in Circulation

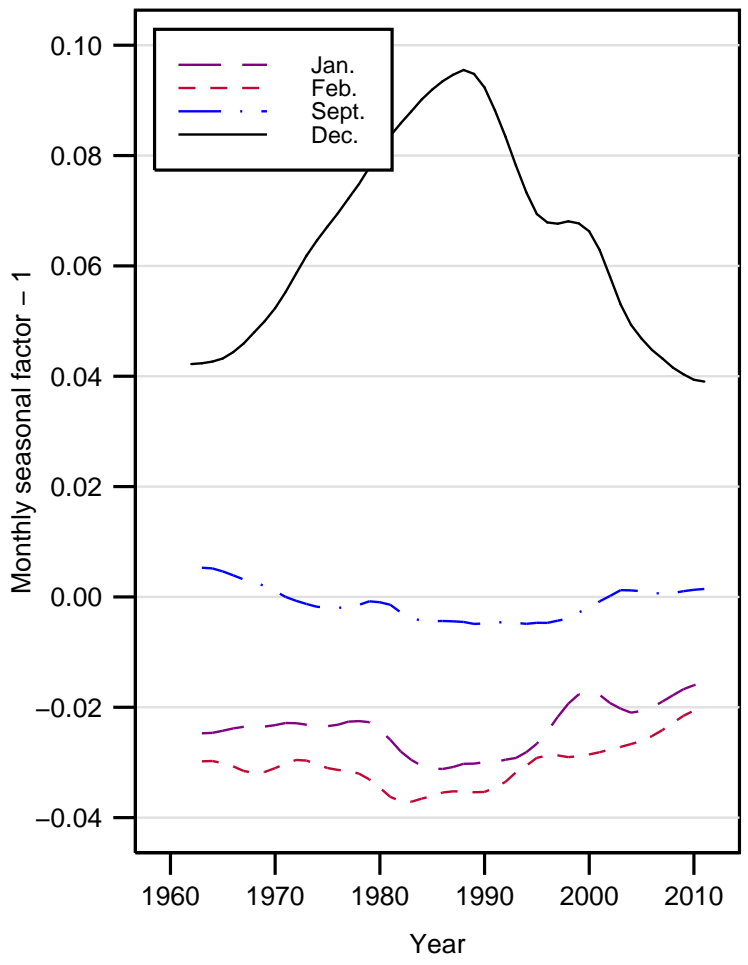

Figure 13B: Seasonal Method Estimated Share of U.S. \$100s Abroad

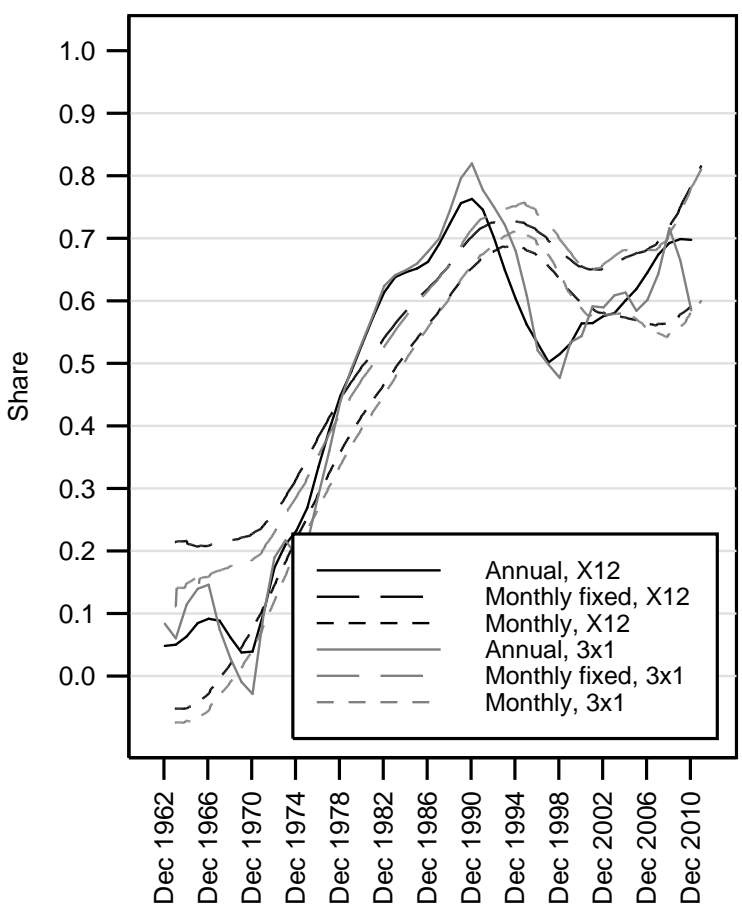

Month 
Figure 14 : Estimated Share of $\$ 100$ s in Circulation Abroad (NY+LA)

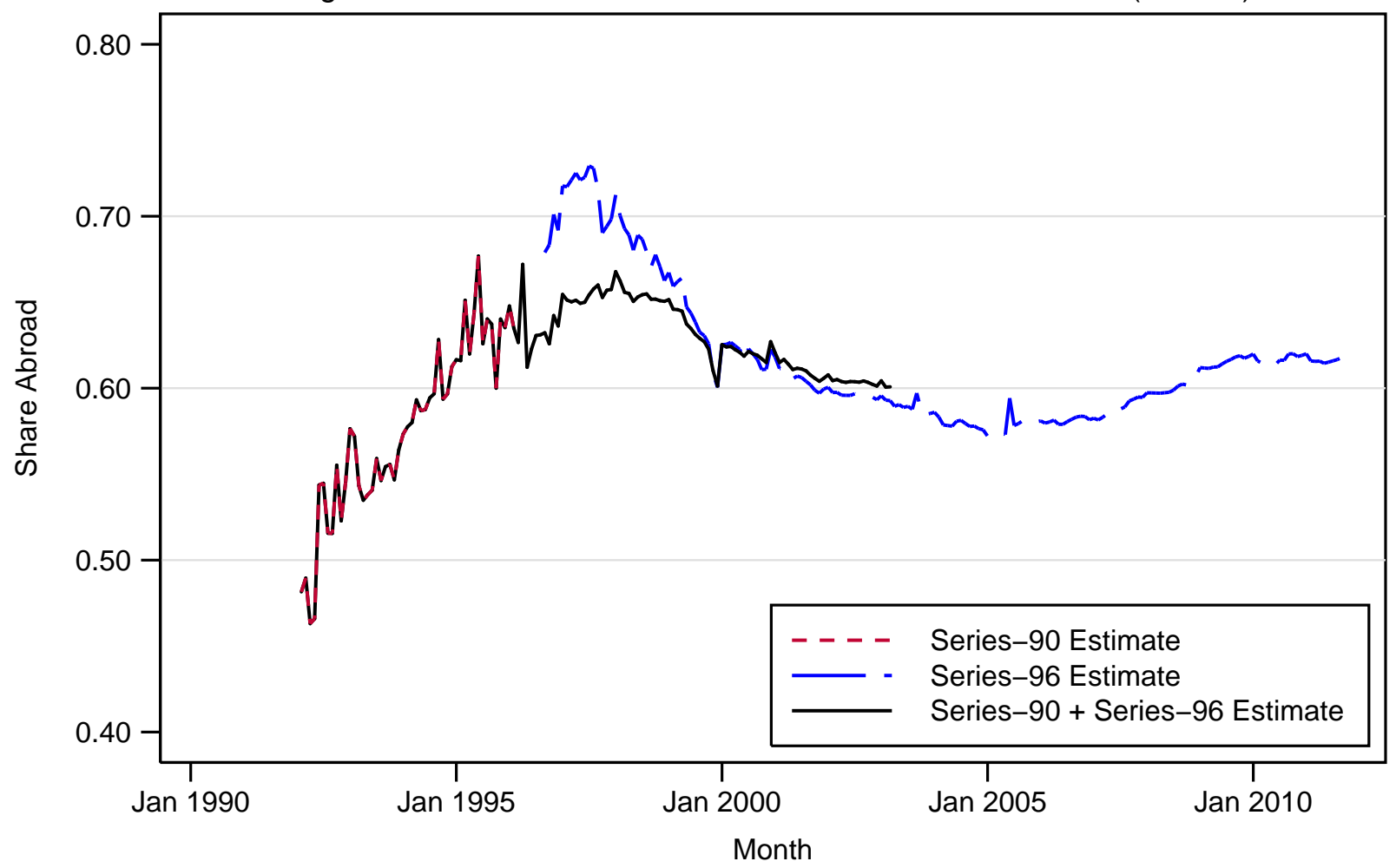

Figure 14A: Total $\$ 100$ s in Circulation $(N Y+L A)$

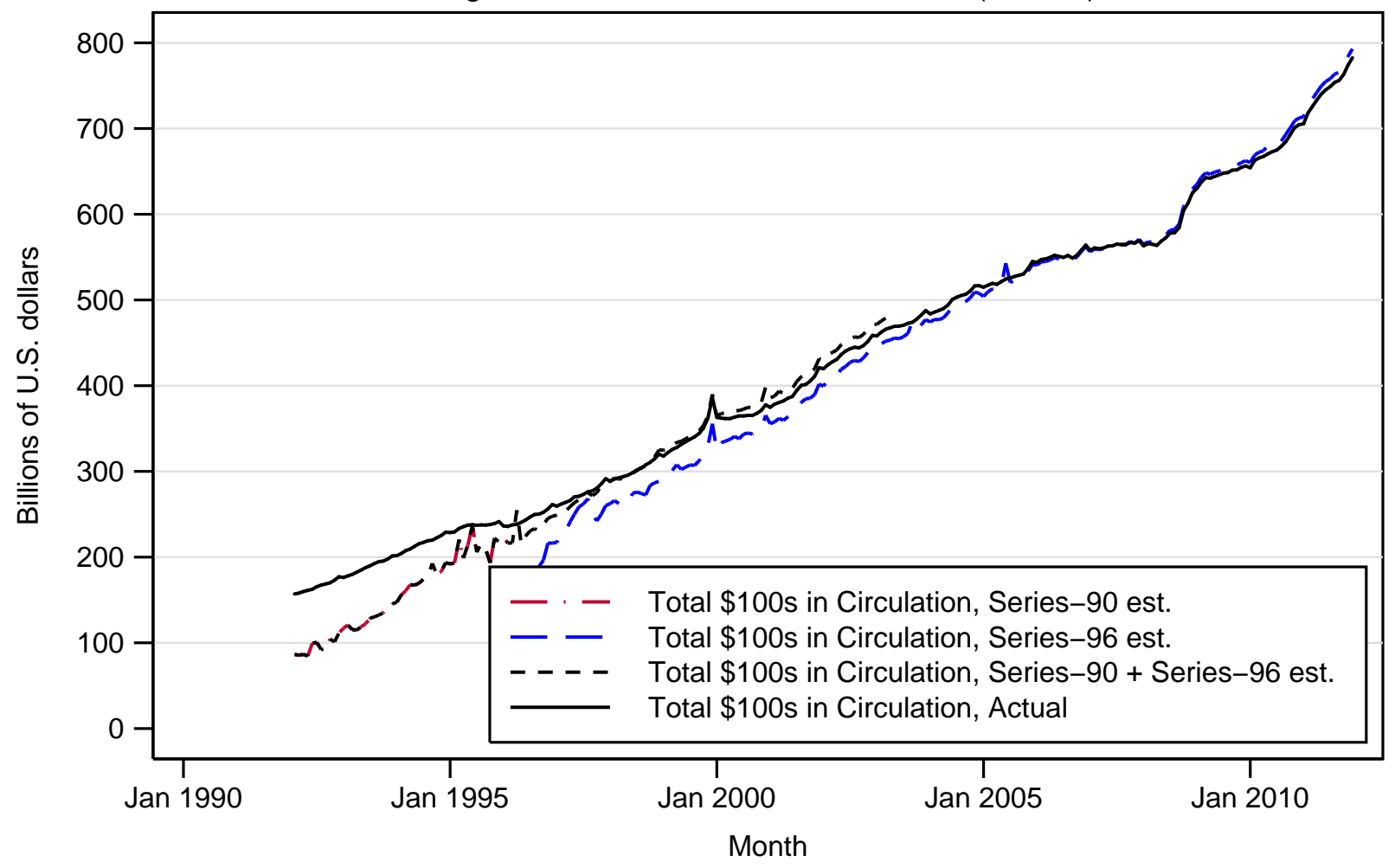


Figure 15A: Growth of Currency, Nominal GDP, and Proxy for Foreign Demand, 1988-2011

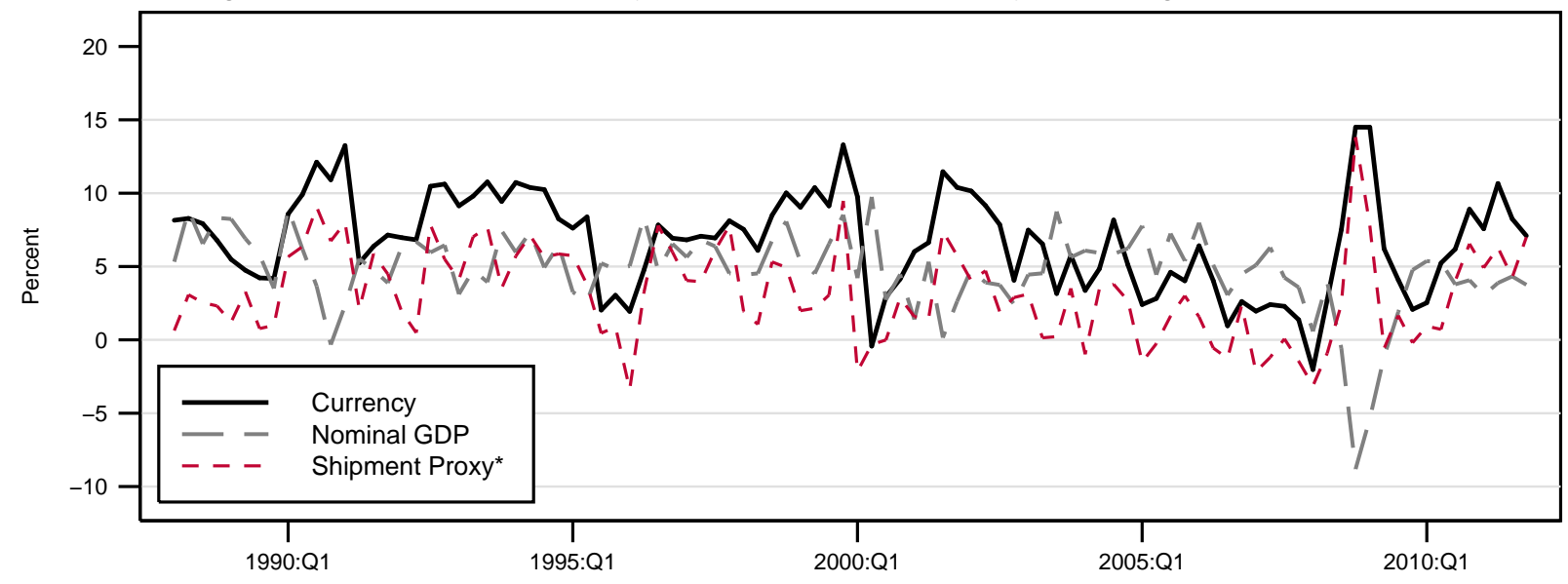

Figure 15B: Estimated Foreign and Domestic Contributions to Currency Increases, 1988-2011

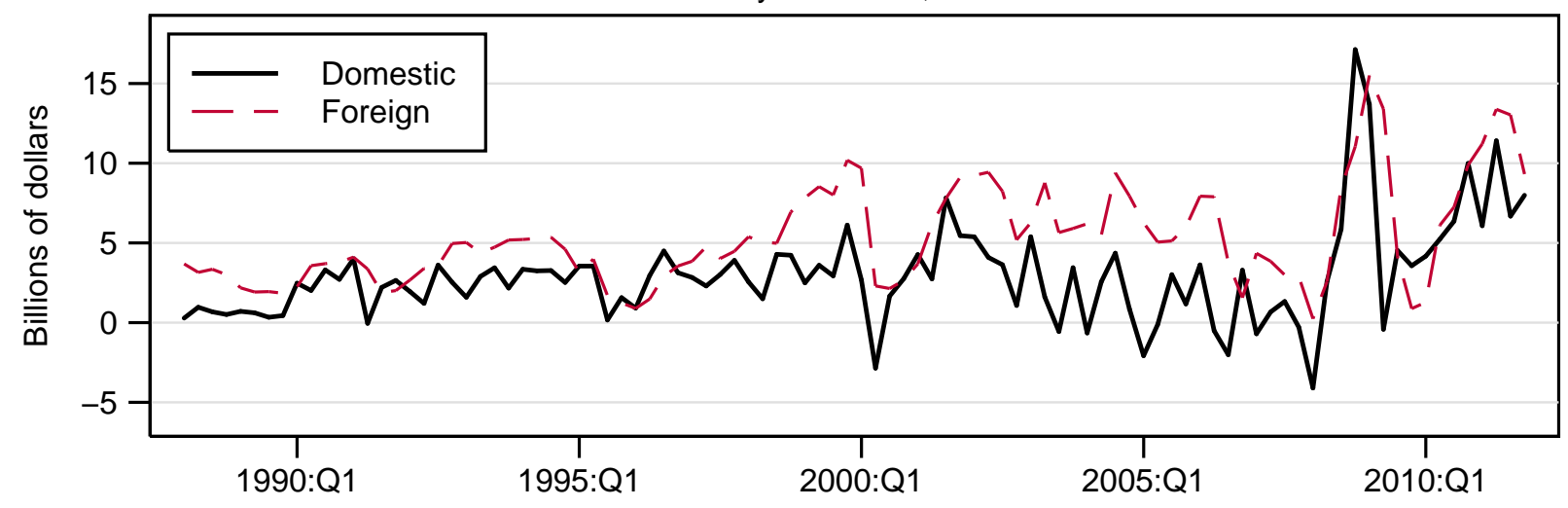

Figure 15C: Estimated Cumulative Contributions of Domestic and Foreign Factors to U.S. Currency Increases, 1988 - 2011

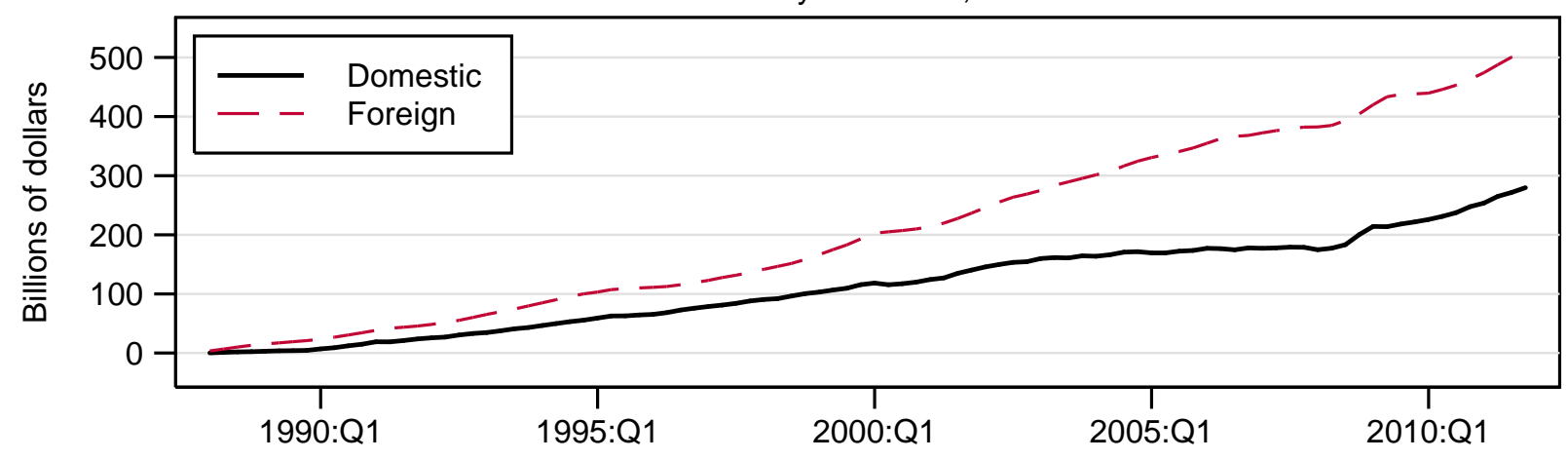

*Foreign proxy is commercial bank shipments adjusted for negative net shipments as described in the text divided by currency stock at the end of the previous period. In Figure 15C, residual assigned equally to domestic and foreign factors. 
Appendix Figure 1: Shares of U.S. and Canadian Currency in Circulation

By Value and Pieces

2011 Average

U.S. Shares, by Value

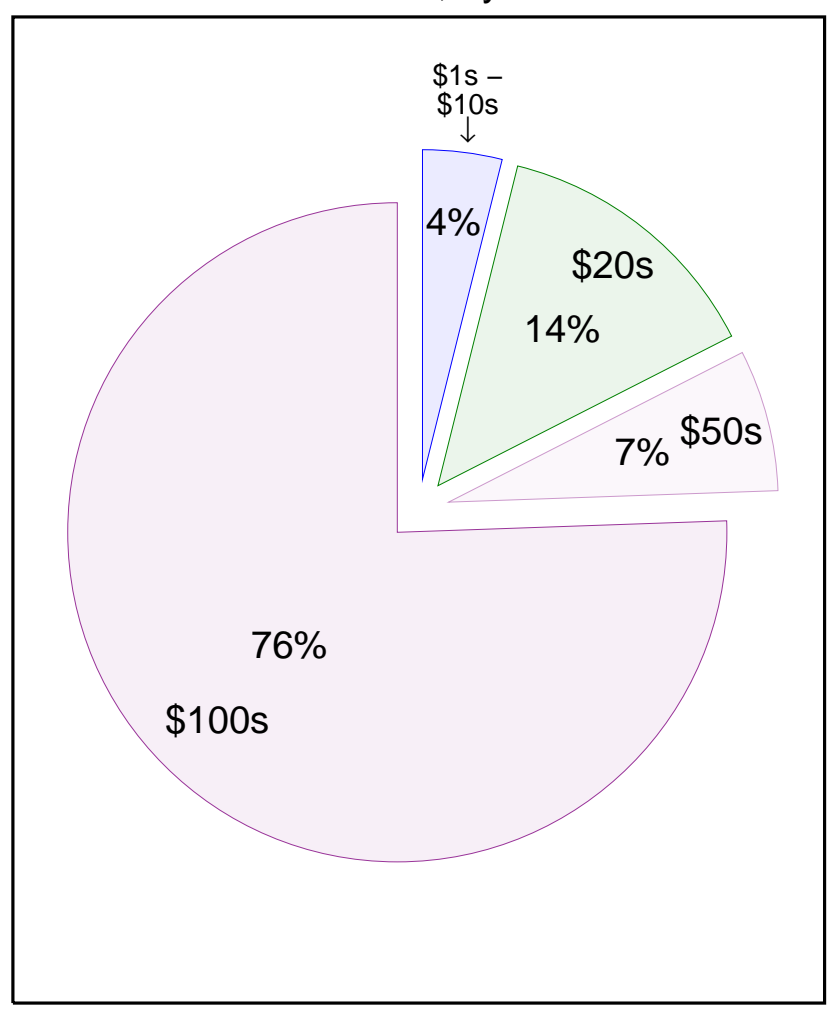

Canadian Shares, by Value

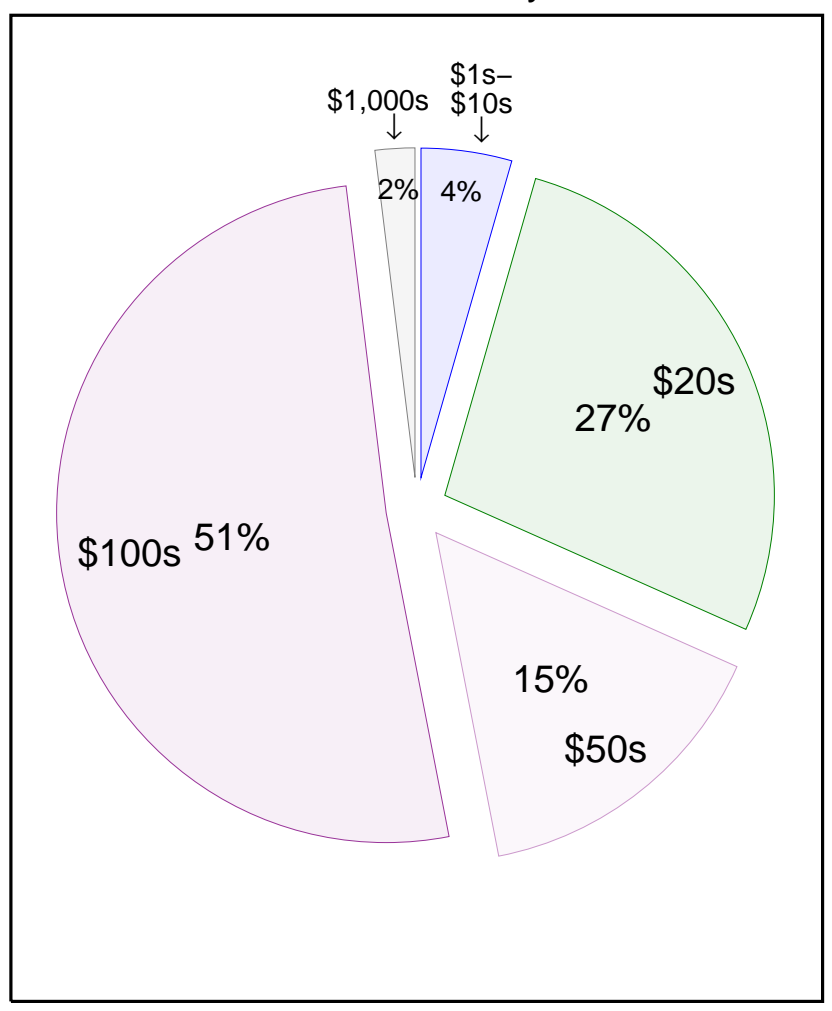

U.S. Shares, Pieces

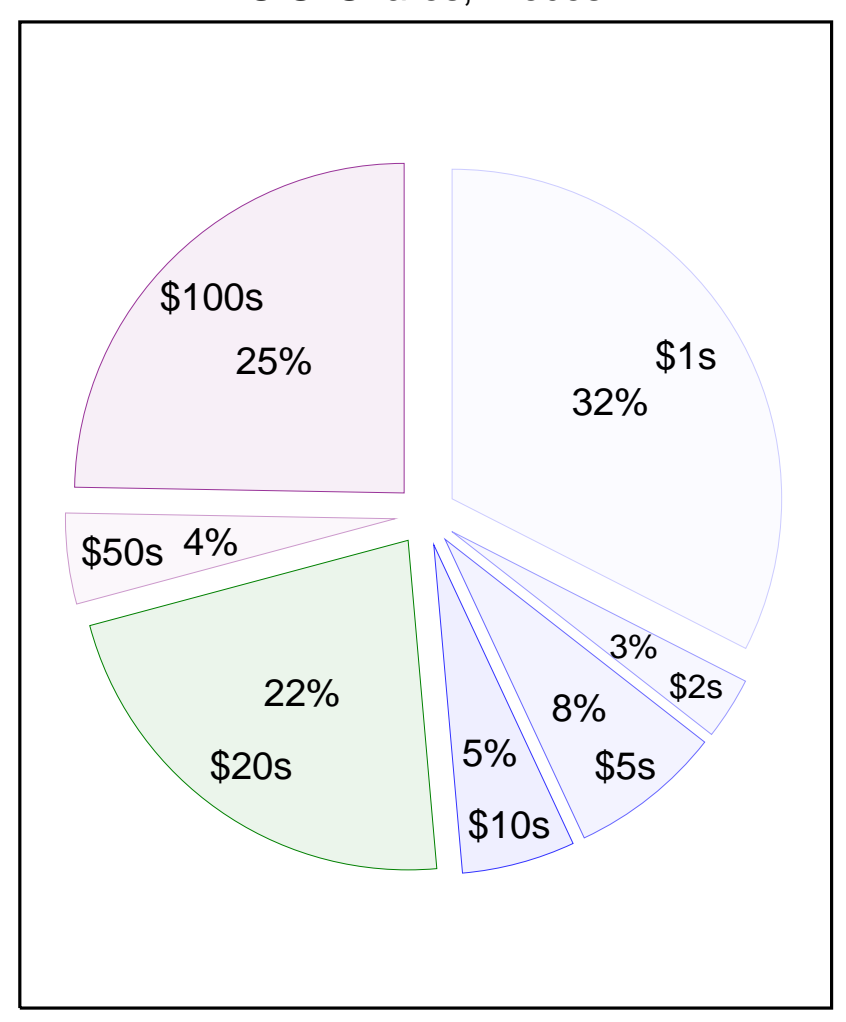

Canadian Shares, Pieces

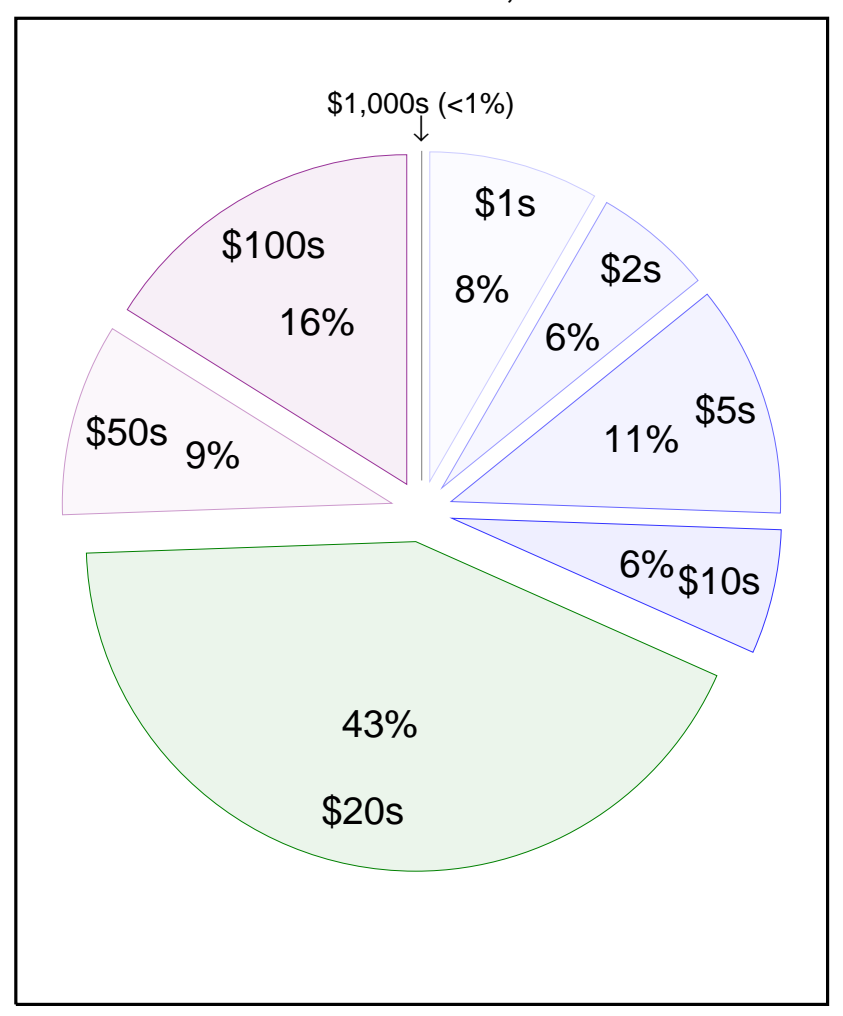




\section{Appendix Figure 2A: Cumulative Change in Currency in Circulation}

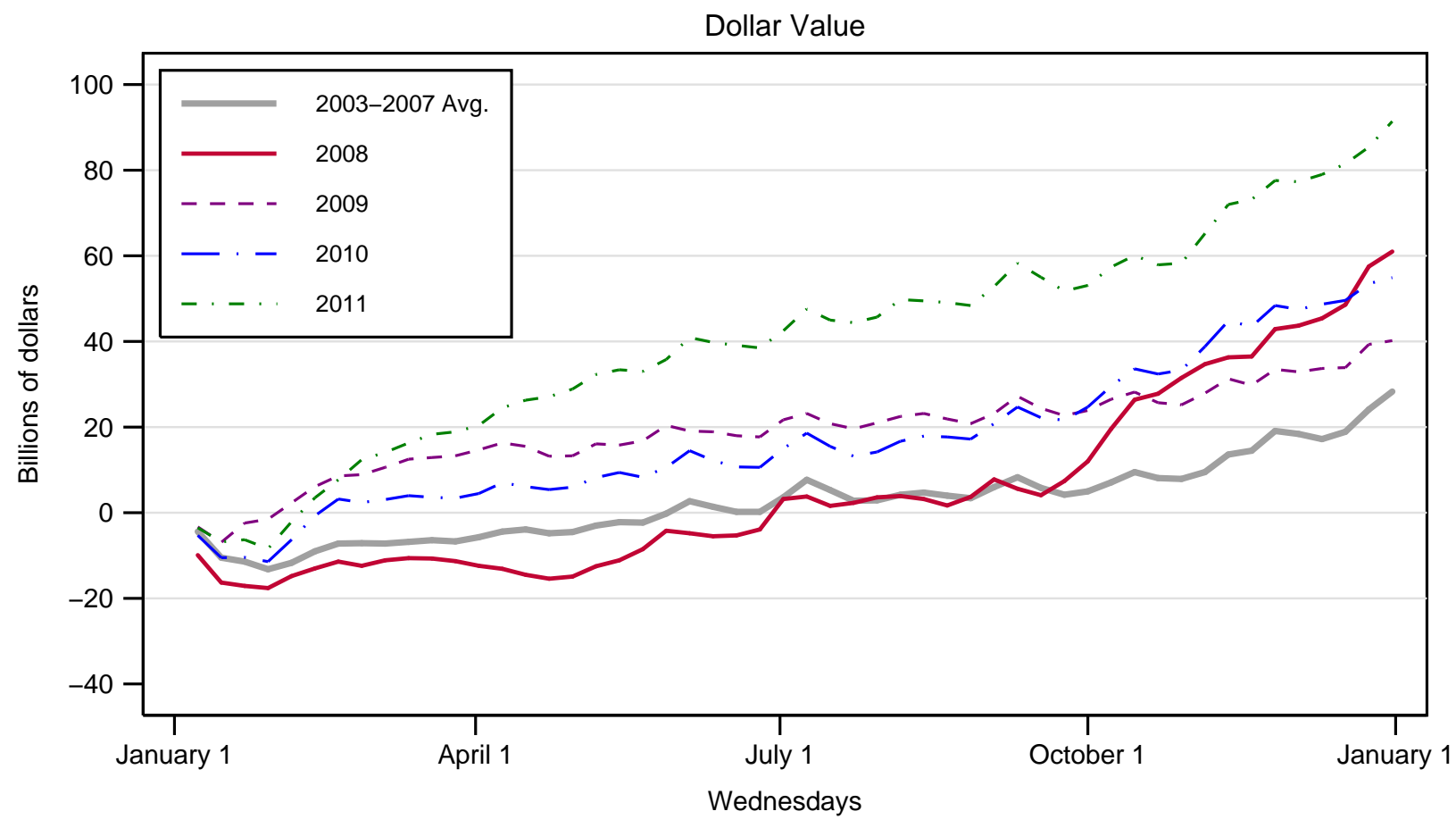

Source. H.4.1 Statistical Release

Appendix Figure 2B: Cumulative Change in Currency in Circulation

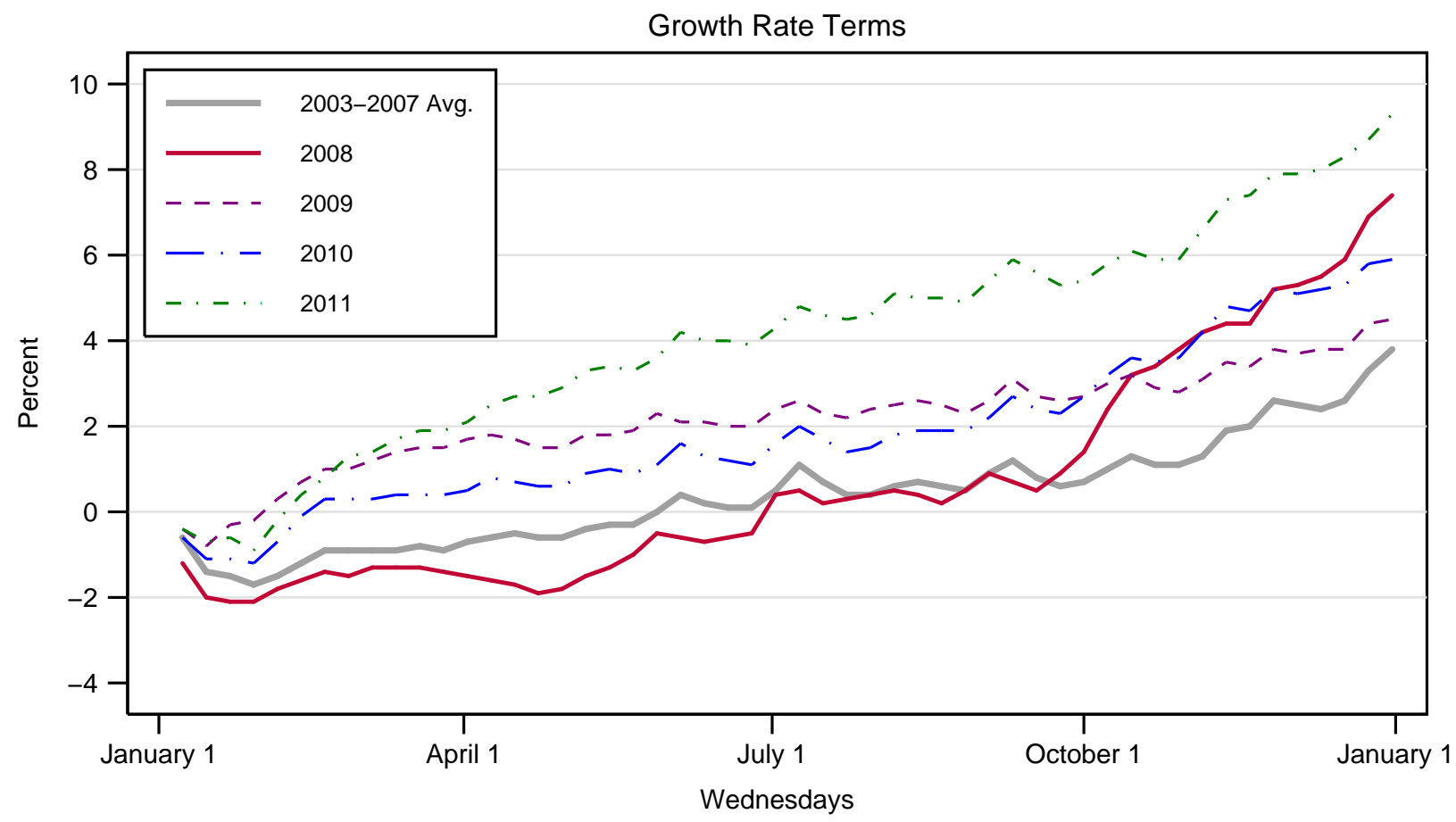

Source. H.4.1 Statistical Release.

Cumulative totals divided by value for last Wednesday of prior year. 


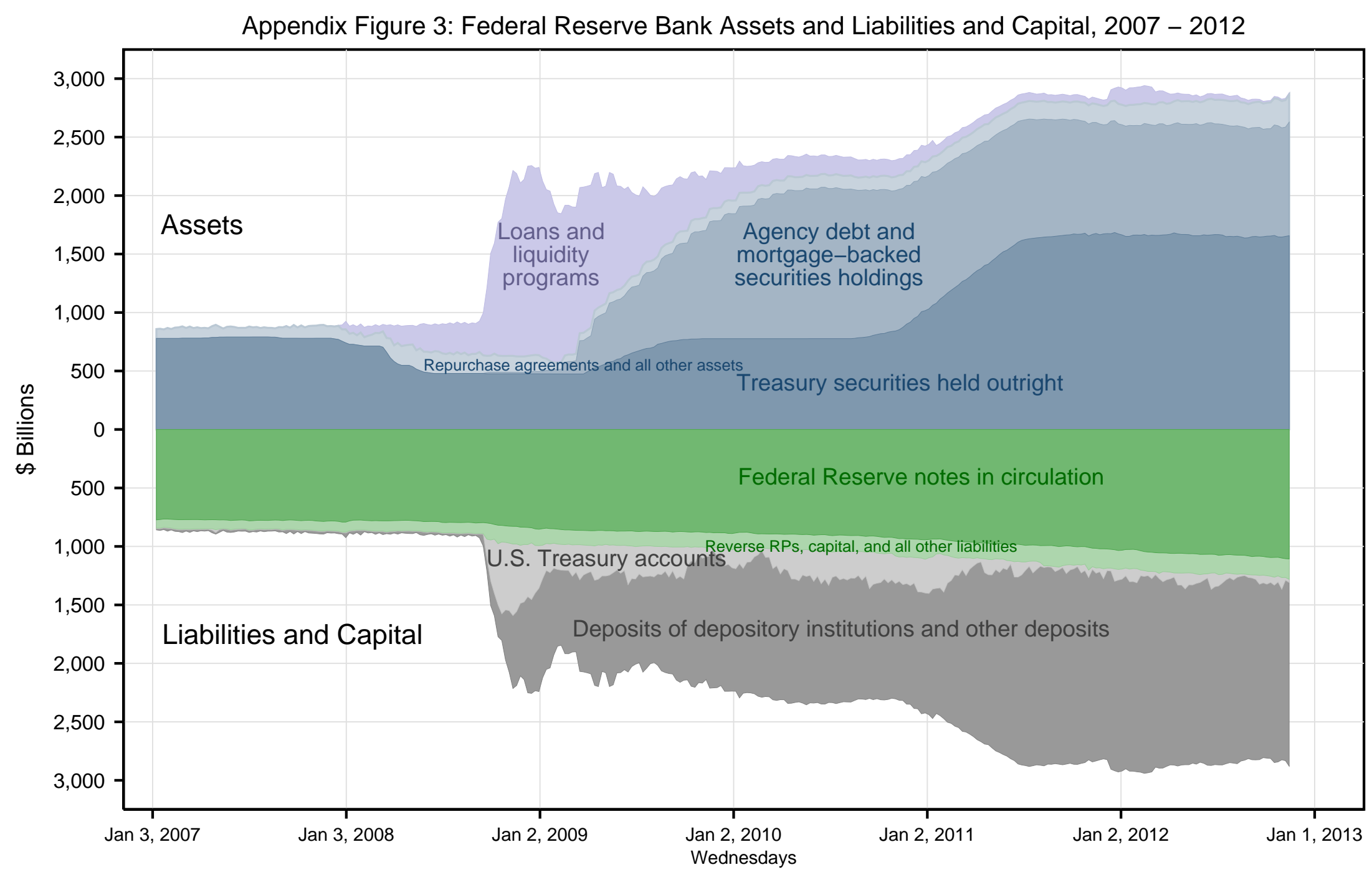

Source: H.4.1 Statistical Release (http://www.federalreserve.gov/releases/h41/). 